\title{
A Novel Combination of Surfactant Addition and Persulfate-assisted Electrokinetic Oxidation for Remediation of Pyrene-Contaminated Soil
}

\author{
M. Abtahi, ${ }^{a}$ S. Jorfi, ${ }^{\text {b, }}{ }^{*}$ N. Mehrabi, ${ }^{c}$ R. Saeedi, ${ }^{d}$ \\ R. Darvishi Cheshmeh Soltani, ${ }^{\mathrm{e}}$ and G. Barzegar ${ }^{\mathrm{f}}$ \\ ${ }^{a}$ Department of Environmental Health Engineering, School of Public \\ Health, Shahid Beheshti University of Medical Sciences, Tehran, Iran \\ bEnvironmental Technologies Research Center, Ahvaz Jundishapur \\ University of Medical Sciences, Ahvaz, Iran \\ 'Department of Environmental Health Engineering, \\ Ahvaz Jundishapur University of Medical Sciences, Ahvaz, Iran \\ ${ }^{\mathrm{d} D e p a r t m e n t}$ of Health Sciences, School of Health, \\ Safety and Environment, Shahid Beheshti University \\ of Medical Sciences, Tehran, Iran \\ eDepartment of Environmental Health Engineering, \\ School of Health, Arak University of Medical Sciences, \\ Arak, Iran \\ fDepartment of Environmental Health Engineering, \\ Behbahan Faculty of Medical Sciences, Behbahan, Iran
}

doi: 10.15255/CABEQ.2017.1204

Original scientific paper
Received: August 29, 2017
Accepted: March 1, 2018

\begin{abstract}
Effect of surfactant addition on persulfate-assisted electrokinetic remediation of pyrene-spiked soil was studied. The influence of effective factors including voltage, surfactant addition, moisture content, and persulfate concentration on the removal of initial pyrene concentration of $200 \mathrm{mg} \mathrm{kg}^{-1}$ were investigated. A complete pyrene removal was observed for voltage of $1 \mathrm{~V} \mathrm{~cm}^{-1}$, saturated conditions, Tween 80 concentration of $20 \mathrm{~mL} \mathrm{~kg}^{-1}$, and persulfate concentration of $100 \mathrm{mg} \mathrm{kg}^{-1}$ after $24 \mathrm{~h}$, corresponding to pyrene mineralization of $61 \%$, based on TPH analysis. The experimental results were best fitted with pseudo-first-order kinetic model with correlation coefficient of 0.968 and rate constant of $0.191 \mathrm{~min}^{-1}$. The main intermediates of pyrene degradation were benzene o-toluic acid, acetic, azulene, naphthalene and decanoic acid. Finally, an unwashed hydrocarbon-contaminated soil was subjected to persulfate-assisted electrokinetic remediation, and a TPH removal of $38 \%$ was observed for the initial TPH content of $912 \mathrm{mg} \mathrm{kg}^{-1}$, under the selected conditions.
\end{abstract}

Keywords:

soil remediation, electrokinetic oxidation, persulfate, surfactant, pyrene

\section{Introduction}

Pyrene is a polycyclic aromatic hydrocarbon (PAH) which may be produced commercially to be utilized as an intermediate in the production of pigments or it can be found in emissions of incomplete combustion of kerosene and diesel. The crystalline structure of pyrene $\left(\mathrm{C}_{16} \mathrm{H}_{10}\right)$ is a four-ring PAHs that is solid at room temperature due to different neutrons $^{1,2}$. The long-term and continuous emission of PAHs into the environment can pose a serious threat to human health and environment through air pollution or soil contamination pathways, e.g., through industrial discharges and some agricultural tradi-

"Corresponding author: sahand369@yahoo.com tions and improper practices of waste disposal ${ }^{3,4}$. Thus, the quick and effective removal of PAHs from the environment as well as reducing their adverse effects seems to be necessary. Three- and four-ring PAHs are in particular associated with soil particles, and due to their low aqueous solubility and high sorption properties, their removal from subsurface environments using traditional technologies, such as soil washing, conventional chemical oxidation or bioremediation, is inefficient ${ }^{5}$. In fact, their removal from fine soil particles is still a major challenge for geo-environments, because of the high variation in their hydraulic conductivity, a lot of specific contaminants, environmental and dynamic conditions, reversible geochemical processes, and the interactions between soil particles and contaminants ${ }^{6,7}$. 
Until now, different physicochemical, thermal, and biological methods have been applied for decontamination of polluted soils. However, these methods are often costly and energy-intensive, and are almost ineffective and could, in turn, remain secondary toxic materials, which are potentially harmful to the environment ${ }^{8-11}$. Thus, electrochemical removal has been considered as a reliable technology for the remediation of contaminated soils ${ }^{12,13}$. The main advantages of electrokinetic remediation (EK remediation) of soil contaminated with petroleum hydrocarbons is that the procedure can be performed as an in-situ or ex-situ technology, in soils with heterogeneous texture and low permeability, or in saturated and unsaturated soils. It is also possible to use electrochemical oxidation for simultaneous removal of heavy metals, radionuclides, and organic pollutants. Flexibility of this technology, high energy efficiency, and cost-effectiveness are also merit$\mathrm{ed}^{14,15}$. EK remediation includes the flow of electrical current in the soil, liquid pole electro-osmotic migration, electrical migration of ions, charged particles and colloids, electrolysis of water in the soil in the vicinity of the electrodes, migration of hydrogen and hydroxide ions into the soil resulting in temporary changes in soil $\mathrm{pH}$, gas production at the electrodes, development of the non-uniform electric field, as well as the production of electro-osmotic flow $^{16,17}$. In EK decomposition of water reactions, oxygen and hydrogen ions $\left(\mathrm{H}^{+}\right)$are produced due to oxidation at the anode, while hydrogen gas and hydroxide ions $\left(\mathrm{OH}^{-}\right)$are made because of the reduction in cathode ${ }^{18,19}$. One of the problems in EK remediation of soil contaminated with organic compounds is that PAHs are hydrophobic, thus reducing the efficiency of the process. One of the approaches in order to enhance the solubility of PAHs is the application of intermediate facilitating factors, such as surfactants ${ }^{20,21}$. Addition of these factors leads to creation of some changes in the fluid properties, such as dielectric constant, $\mathrm{pH}$, fluid viscosity, as well as changes in surface properties of soil particles ${ }^{22,23}$. Among the surfactants, non-ionic materials have been widely used for transferring non-polar organic substances by electro-osmotic flow. Indeed, surfactants have lower dielectric constant and higher viscosity than water. Consequently, the addition of these facilitators not only reduces the electro-osmotic flow, but also increases the solubility of $\mathrm{PAHs}^{24}$. Another problem concerning EK remediation is the great amount of time required to remove contaminants from the soil. This problem could be solved in the EK remediation process using other oxidations. The application of persulfate as an oxidizing agent can improve the efficiency and significantly reduce the required time for soil decontamination ${ }^{25,26}$. The process of oxidation by means of activated persulfate is a promising approach, due to stability, reactivity, solubility, oxidizing properties, and high amount of organic matter degradation ${ }^{27}$. Persulfate $\left(\mathrm{S}_{2} \mathrm{O}_{8}{ }^{2-}\right)$, with standard oxidation potential of $E^{0}=2.01 \mathrm{~V}$, is a novel approach applied in chemical oxidation, and has been considered a promising remediation technique of recalcitrant organics. Moreover, $\mathrm{S}_{2} \mathrm{O}_{8}{ }^{2-}$ activation leads to production of sulfate radical $\left(\mathrm{SO}_{4}^{-\cdot}, E^{0}=2.7 \mathrm{~V}\right)$, as a strong oxidant for the degradation of organic matter, even at neutral $\mathrm{pH}$ values, and acts more selectively for destruction of compounds with carboncarbon double bonds and benzene rings ${ }^{28,29}$. Persulfate activation would be carried out via different approaches, such as heat, metal and base transition (elevated $\mathrm{pH}>11$ ), UV-radiation, electron-beam and ultrasonication ${ }^{30}$. For soil remediation, UV irradiation is not capable of penetrating the soil matrix, and alkaline activation requires high quantities of alkaline substances. Furthermore, transition of metal-catalyzed activation (e.g., $\mathrm{Fe}^{2+}$ ) exhibits best results in strict $\mathrm{pH}$ value range of $2-4$, and metal can act as a radical scavenger ${ }^{31}$. Thermally activated persulfate is known as a green source of sulfate radicals and has been previously applied to remove organic pollutants ${ }^{32}$. Thermal activation of persulfate also has many benefits, like the enhancement of solubility of slightly soluble PAHs, increase in efficiency of reaction and mineralization, and the consumption of fewer chemical substances ${ }^{33}$. Because of the heat generation through EK remediation, persulfate activation can be accomplished at the same time.

Integrated EK remediation with persulfate can be used to overcome limitations of conventional EK remediation and facilitate the distribution of persulfate in soils with low permeability. At the same time, it can directly cause oxidation-reducting reactions in the soil ${ }^{34}$. This study is intended to remediate pyrene-contaminated soil using persulfate-assisted EK remediation, and to use its results for the unwashed real hydrocarbon-polluted soils.

\section{Materials and methods}

\section{Chemicals}

All chemicals applied in the present research, including pyrene, sulfuric acid, soda, methanol, n-hexane, acetone, Tween 80 , acetonitrile and sodium persulfate were analytical-grade purchased from Merck, Germany, and all solutions were prepared with deionized water and kept at $4{ }^{\circ} \mathrm{C}$, prior to experiments. 


\section{Soil sample}

All soils were obtained from an oil manufacturing district in southern Iran. The soil samples were collected from the upper layers $(0-40 \mathrm{~cm})$ by soil cores, air-dried, and passed through a 2-mm sieve. The process of homogenization of soil grains was then performed by a shaker, followed by washing thrice with acetone, autoclaving, and storing in nonreactive plastic bags at $4{ }^{\circ} \mathrm{C}$. Since the washed soil still contained pyrene, a determined amount of pyrene was dissolved in $n$-hexane and added to the soil to achieve a final soil concentration of $200 \mathrm{mg} \mathrm{kg}^{-1}$ in all samples. It was mixed vigorously and left under hood for $24 \mathrm{~h}$ until the n-hexane evaporated. The pyrene stock solution was added to a shaker for 1 minute before spiking ${ }^{35}$. Also, an unwashed soil sample of the same origin and without washing was used as naturally contaminated soil. The X-ray diffraction (XRD) patterns of the soil sample were recorded by X-ray diffractometer (Model: GNRMPD3000) using $\mathrm{Cu}$ anode at $\lambda=0.15060 \mathrm{~nm}$, voltage $=$ at $40 \mathrm{kV}$, and current intensity $=30 \mathrm{~mA}$. $\mathrm{X}$-ray Fluorescence (XRF) was applied for finding the chemical substances of soil particles. The pyrene and its degradation metabolites were also determined by GC-MS (Model: Agilent 7890, USA) with HP-5MS capillary column $(30 \mathrm{~m} \times 0.25 \mathrm{~mm} \times 0.25$ $\mu \mathrm{m}$ film thickness, $5 \%$ Phenyl - $95 \%$ Methyl Siloxane phase). The carrier gas (helium) was fed with a fixed $1 \mathrm{~mL} \mathrm{~min}^{-1}$ flow rate. The oven temperature was fixed to $40{ }^{\circ} \mathrm{C}$ for $1 \mathrm{~min}$, followed by an enhancement to $300{ }^{\circ} \mathrm{C}$ at $5{ }^{\circ} \mathrm{C} \mathrm{min}^{-1}$ and kept constant for $3 \mathrm{~min}$. Ultimately, the sample was poured in instrument with 10:1 splitting ratio. Mass spectra were obtained by electron impact (EI) at 70 $\mathrm{eV}$ with the full scan mode.

\section{Lab-scale experimental setup}

The reactor was a cube Plexiglas chamber (Supplementary file S1) consisting of 10 houses, each with a length of $30 \mathrm{~cm}$, width of $10 \mathrm{~cm}$, and height of $20 \mathrm{~cm}$, divided into 10 completely equal sections using nine separating walls in the longitudinal sector. Other facilities in the reactor included 2 pairs of graphite electrodes with a thickness of 4 $\mathrm{mm}$, width of $4 \mathrm{~cm}$, and length of $15 \mathrm{~cm}$ for each section, and a DC power supply (Model: Zx 200). The voltage was adjustable between $0-100 \mathrm{~V} \mathrm{~cm}^{-1}$.

\section{Experimental procedure}

All the experiments were carried out in batch mode operation. In fact, for determination of the optimum conditions of the experimental factors, such as voltage $\left(0.3-1.5 \mathrm{~V} \mathrm{~cm}^{-1}\right)$, moisture content $(10-100 \%)$, effect of Tween 80 as a chemical surfactant $\left(0-40 \mathrm{~mL} \mathrm{~kg}^{-1}\right)$, effect of sodium persulfate $\left(0-100 \mathrm{mg} \mathrm{kg}^{-1}\right)$ and reaction time $(0-120 \mathrm{~h})$ on pyrene removal, were investigated consecutively based on one factor at a time experimental design. Additionally, an unwashed soil sample was subjected to persulfate-assisted EK remediation based on the selected conditions.

\section{Analytical methods}

The remaining concentrations of pyrene in the soil samples were extracted using an ultrasonic instrument based on EPA method $3550 \mathrm{~B}^{36}$. Briefly, the sample was put in a special tube containing n-hexane and acetone with 1:1 v/v ratio. With completion of extraction, the process of centrifugation of sample was carried out for $10 \mathrm{~min}$ at $6000 \mathrm{rpm}$, followed by filtration using polytetrafluoroethylene (PTFE). A specific amount of filtered solution was separated in order to perform the analysis. The pyrene concentration was obtained using gas chromatography (GC) system (Chrompack CP 9001) equipped with a flame ionization detector (FID) using (HP-5) capillary column $(30 \mathrm{~m}, 0.32 \mathrm{~mm}$ i.d. and $0.2 \mu \mathrm{m}$ film thickness). Nitrogen was used as

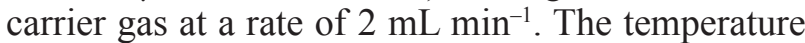
program was as follows: column temperature was held at $120{ }^{\circ} \mathrm{C}$ for $1 \mathrm{~min}$, and then raised to $240{ }^{\circ} \mathrm{C}$ at a rate of $20^{\circ} \mathrm{C} \mathrm{min}^{-1}$, then held for $1 \mathrm{~min}$. The temperatures of injector and detector were fixed at 250 and $300{ }^{\circ} \mathrm{C}$, respectively. Removal was analyzed through quantifying initial and final pyrene concentration according to Eq. (1):

$$
R(\%)=\left(\frac{C_{0}-C_{t}}{C_{0}}\right) \cdot 100
$$

where, $C_{0}$ and $C_{t}$ are the initial and residual pyrene concentrations $\left(\mathrm{mg} \mathrm{L}^{-1}\right)$. Pyrene recovery rate was about $85 \%$ immediately after spiking. Considering the value of $15 \%$ as a non-extracted portion of pyrene from the soil, we multiplied all raw data by a factor of 1.15. Soil moisture, EC, and $\mathrm{pH}$ were analyzed based on ASTM (D4972-13) ${ }^{37}$. The soil texture was determined according to the method described by ASTM (D6913M-17) ${ }^{38}$.

\section{Results and discussion}

\section{Soil analysis}

Some selected chemical and physical characteristics of the soil are presented in Table 1. Accordingly, the studied soil with $32 \%$ clay was of the clay-loam. $\mathrm{SiO}_{2}$ and $\mathrm{CaO}$ also accounted for most of the mineral parts of the soil. LOI of $22 \%$ made a significant portion of the soil mass. This was because the soil was contaminated with different types of petroleum compounds. Furthermore, the pres- 
Table 1 -Characteristics of the soil sample along with XRF results

\begin{tabular}{|c|c|}
\hline Characteristic & Value (\%) \\
\hline Clay & 32 \\
\hline Silt & 37 \\
\hline Sand & 31 \\
\hline Moisture & 27.8 \\
\hline $\mathrm{EC}\left(\mu \mathrm{S} \mathrm{cm}^{-1}\right)$ & 76000 \\
\hline $\mathrm{pH}$ & 6.8 \\
\hline $\mathrm{Na}$ & 4.4 \\
\hline $\mathrm{TiO}_{2}$ & 0.28 \\
\hline $\mathrm{MgO}$ & 4.8 \\
\hline $\mathrm{Cl}$ & 7.5 \\
\hline $\mathrm{Fe}_{2} \mathrm{O}_{3}$ & 3.3 \\
\hline $\mathrm{Al}_{2} \mathrm{O}_{3}$ & 4.5 \\
\hline $\mathrm{K}_{2} \mathrm{O}$ & 1.5 \\
\hline L.O.I & 22.6 \\
\hline $\mathrm{SiO}_{2}$ & 26.5 \\
\hline $\mathrm{CaO}$ & 24.3 \\
\hline $\mathrm{La}$ and $\mathrm{Lu}$ & $1>$ \\
\hline
\end{tabular}

ence of 5.7 wt $\%$ of chloride ions indicated severe salinity of the studied soil. According to the results of XRD analysis (results are not presented and can be found in supplementary files), the dominant crystalline phases of soil samples included calcite $\left(\mathrm{CaCO}_{3}\right)$, quartz $\left(\mathrm{SiO}_{2}\right)$, halite $(\mathrm{NaCl})$, dolomite $\left(\mathrm{CaMg}\left(\mathrm{CO}_{3}\right)_{2}\right.$, gypsum $\left(\mathrm{CaSO}_{4} \cdot 2 \mathrm{H}_{2} \mathrm{O}\right)$ and clays.

\section{EK remediation}

The results indicated that any changes in the applied voltage directly affected the electro-osmotic flow in a way that, with an increase in voltage, the electro-osmotic flow increased. Voltage changes, however, have the maximum effect on the soil geochemical characteristics that critically affect the electro-osmotic flow. Moreover, the voltage of $1 \mathrm{~V} \mathrm{~cm}^{-1}$ promotes the development and maintenance of the electro-osmotic flow during the reac$\operatorname{tion}^{39,40}$. Effect of voltage in the range of 3.0 to 1.5 $\mathrm{V} \mathrm{cm}^{-1}$ on the efficiency of the EK remediation process in removing pyrene from soil was examined. All the other variables, including natural soil $\mathrm{pH}$ equal to $7 \pm 0.3$, reaction time of $120 \mathrm{~h}$, initial pyrene concentration of $200 \mathrm{mg} \mathrm{kg}^{-1}$, humidity of $50 \%$, and zero concentrations of Tween 80 and persulfate were kept constant. Pyrene removal efficiency increased as the voltage increased, but no significant difference was observed between the voltages 1 and $1.5 \mathrm{~V} \mathrm{~cm}^{-1}$ ( $p$ value $>0.05$ ). Pyrene removal efficiencies in $0.3,0.5,0.7,1$, and $1.5 \mathrm{~V} \mathrm{~cm}^{-1}$ were 28, 31, 40, 46 and $47.5 \%$, respectively (Fig. 1a).
At the beginning of the reaction, due to the movement of the electro-osmotic flow from the anode towards the cathode, ionic migration of the contaminants exhibited an increasing trend ${ }^{41,42}$. In fact, due to the stronger electric field and the resulting higher current density through the electrodes, most of the processes associated with the removal of contaminants, such as electro-osmosis and electrical migration, occur more efficiently and thus more contaminants are eliminated ${ }^{43}$.

In effect, the high natural EC in loamy soils contributed to the high electro-osmotic flow at the beginning of the reaction. After the maximum streaming, access of water pole and moving ions $\left(\mathrm{H}^{+}\right.$and $\left.\mathrm{OH}^{-}\right)$, due to the electrolysis of water molecules and deposition of ions in the area of the cathode, decreased and resulted in reduced electric current and constant amount of pollutant removal ${ }^{44}$. In this study, due to lower power consumption and non-significant difference ( $p$ value $>0.05$ ) in removal efficiency of voltages 1 and $1.5 \mathrm{~V} \mathrm{~cm}^{-1}$, we alternatively selected voltage of $1 \mathrm{~V} \mathrm{~cm}^{-1}$ for the rest of the experiments. In addition, pseudo-first-order degradation rate constants were 0.0045 and $0.0046 \mathrm{~h}^{-1}$ for voltages of 1 and $1.5 \mathrm{~V} \mathrm{~cm}^{-1}$, respectively, indicating a non-significant difference between them (Fig. 1b).

\section{Effect of moisture content}

In the selected conditions including voltage of $1 \mathrm{~V} \mathrm{~cm}^{-1}$, and the other variables, such as pyrene concentration of $200 \mathrm{mg} \mathrm{kg}^{-1}$, reaction time of 120 $\mathrm{h}$, natural soil $\mathrm{pH}$ equal to $7 \pm 0.3$, zero concentration of Tween 80 and sodium persulfate, the effect of moisture content in the range of $10 \%, 25 \%, 50 \%$ and $100 \%$ on the efficiency of the EK remediation for pyrene removal were studied. Pyrene removal efficiency for moisture contents of 10, 25, 50 and $100 \%$ were 15, 29, 45, and $64 \%$, respectively (Fig. $1 \mathrm{c})$. The higher the moisture content, the greater is the electrical current established, and thus the more $\mathrm{H}^{+}$ions are produced ${ }^{45}$. When an electric field is established in moist soils, electrolysis of water molecules occurs, which reduces the moisture content of the soil. Changes in moisture content took place in the cathode, due to the electro-osmotic flow of water molecules from the anode to the cathode. Although the electro-osmotic streaming reduces with increasing $\mathrm{pH}$ and ion concentration in the liquid, the higher the current, the more efficient is the contaminants removal process ${ }^{44}$. Rather than removal efficiency, which was the highest in moisture content of $100 \%$, the reaction rate constant was much higher for saturation condition $\left(0.0087 \mathrm{~h}^{-1}\right)$ compared to moisture content of $50 \%\left(0.0043 \mathrm{~h}^{-1}\right)$ (Fig. 1d). Therefore, the moisture content of $100 \%$ was selected for the rest of the experiments. 
(a)

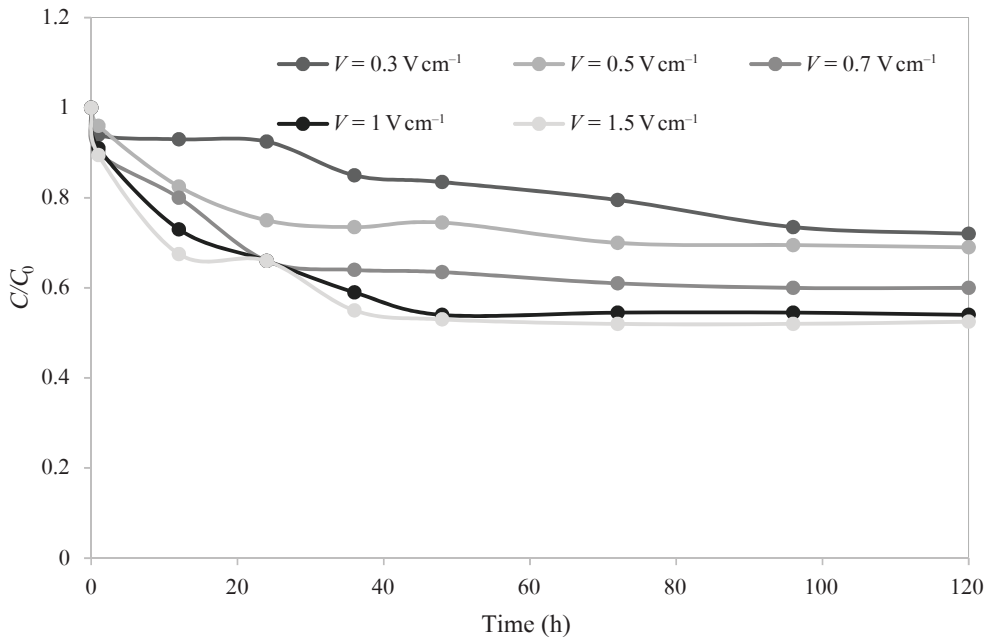

(b)

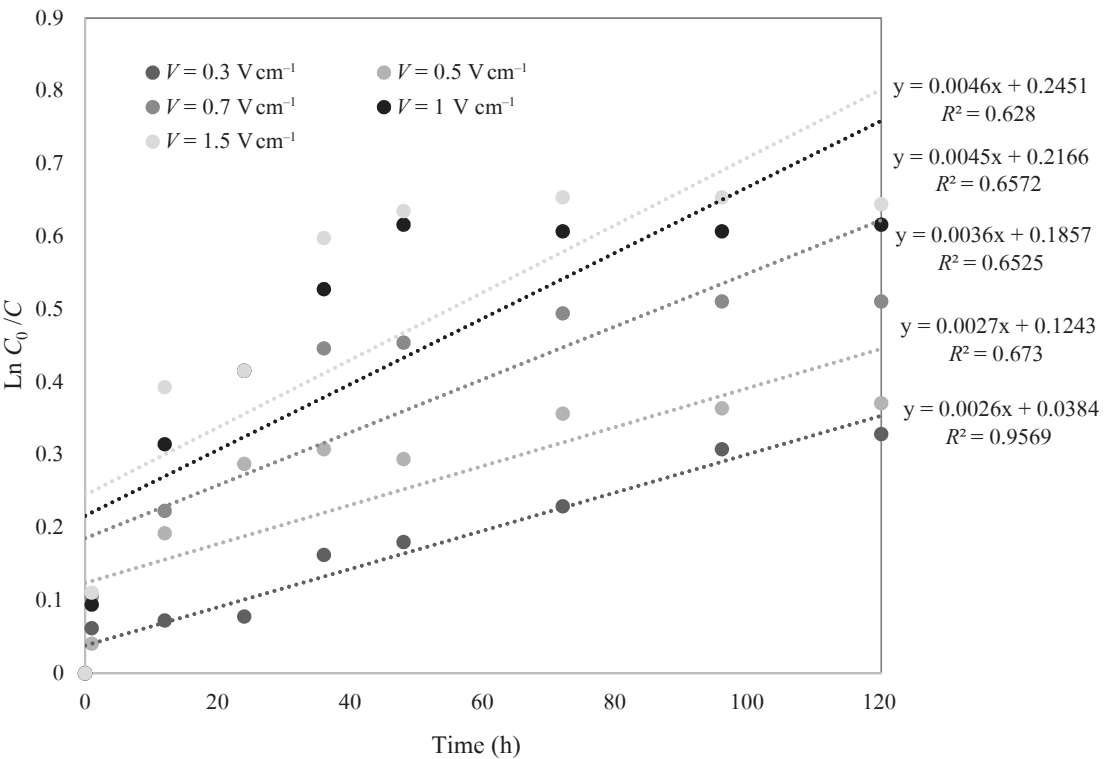

(c)

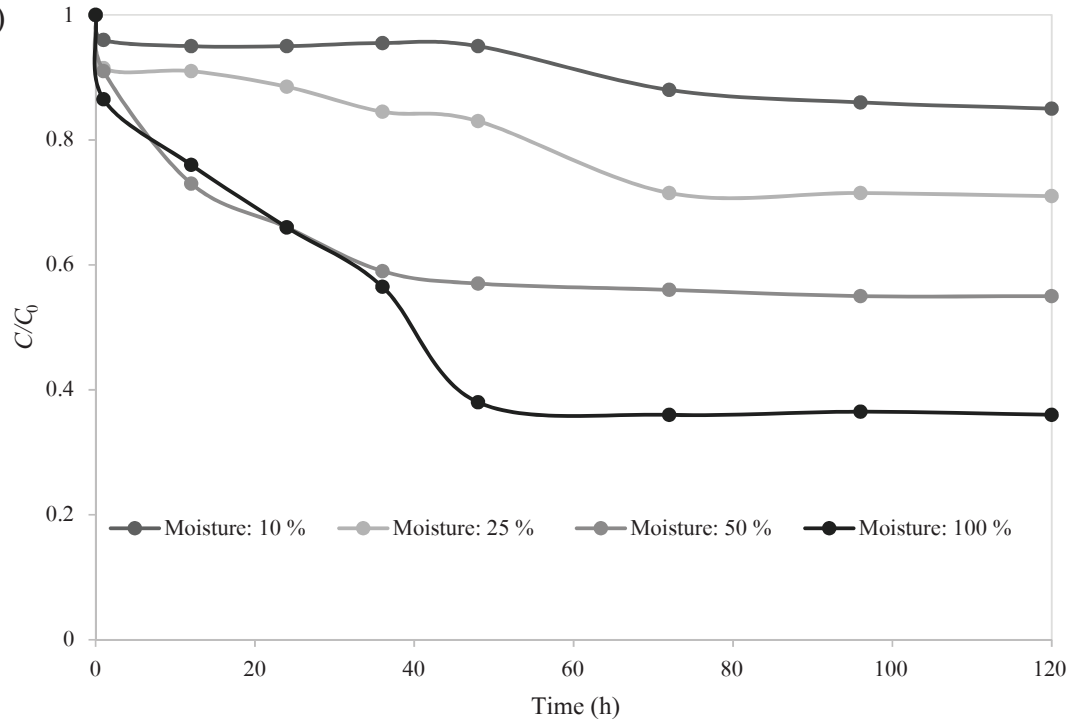

Fig. 1 - Effect of operating parameters on pyrene removal through EK remediation; initial pyrene: $200 \mathrm{mg} \mathrm{kg}^{-1}, \mathrm{pH}: 7 \pm 0.5$, reaction time: $120 \mathrm{~h}$, a) effect of voltage variations, and b) pseudo-first-order kinetic modeling, Tween 80: $0 \mathrm{mg} \mathrm{kg}^{-1}$, persulfate: $0 \mathrm{mg} \mathrm{kg}^{-1}$, moisture: $50 \%$, c) effect of moisture content, and d) pseudo-first-order kinetic modeling, Tween 80: $0 \mathrm{mg} \mathrm{kg}^{-1}$, persulfate: $0 \mathrm{mg} \mathrm{kg}-1$, voltage: $1 \mathrm{~V} \mathrm{~cm}^{-1}$, e) effect of Tween 80, and f) pseudo-first-order kinetic modeling, persulfate: $0 \mathrm{mg} \mathrm{kg}^{-1}$, voltage: $1 \mathrm{~V} \mathrm{~cm}^{-1}$, moisture content: $100 \% \mathrm{~g}$ ) effect of persulfate addition, and h) pseudo-first-order kinetic modeling, Tween 80: $20 \mathrm{~mL} \mathrm{~kg}{ }^{-1}$, voltage: $1 \mathrm{~V} \mathrm{~cm}^{-1}$, moisture content: $100 \%$ 
(d)

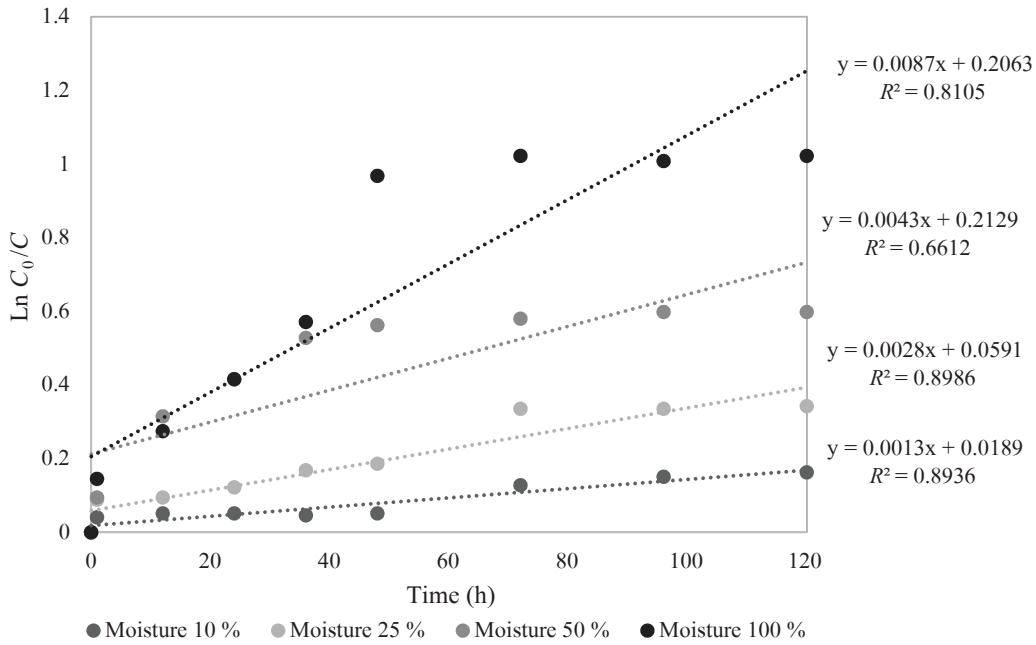

(e)

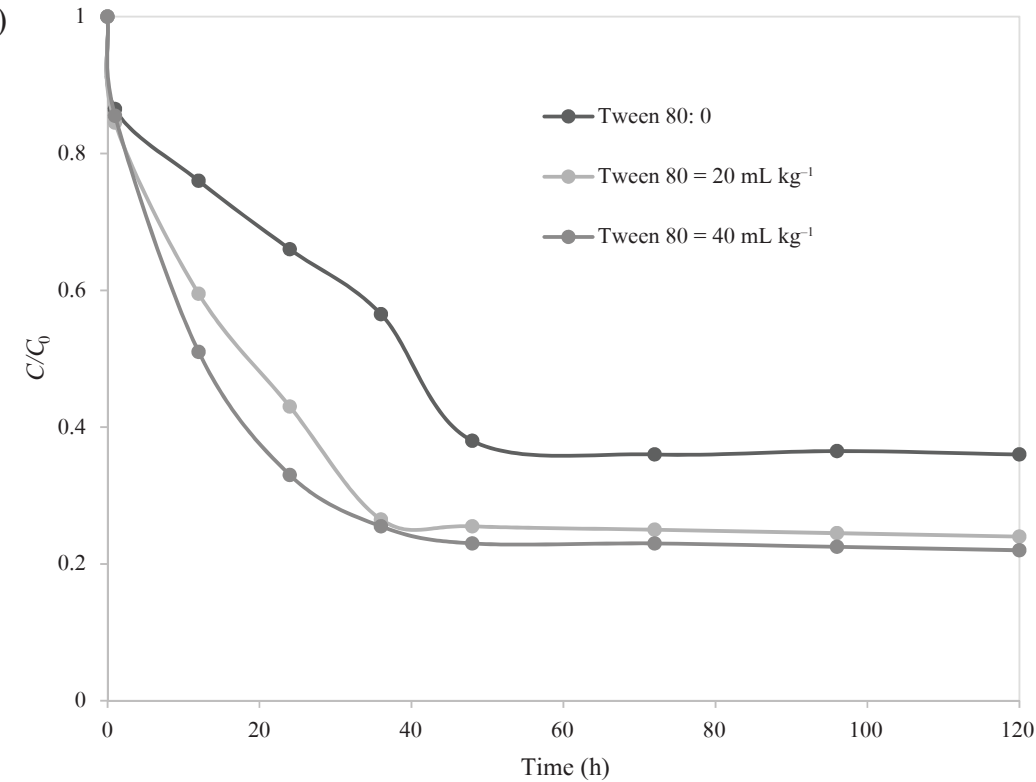

(f)

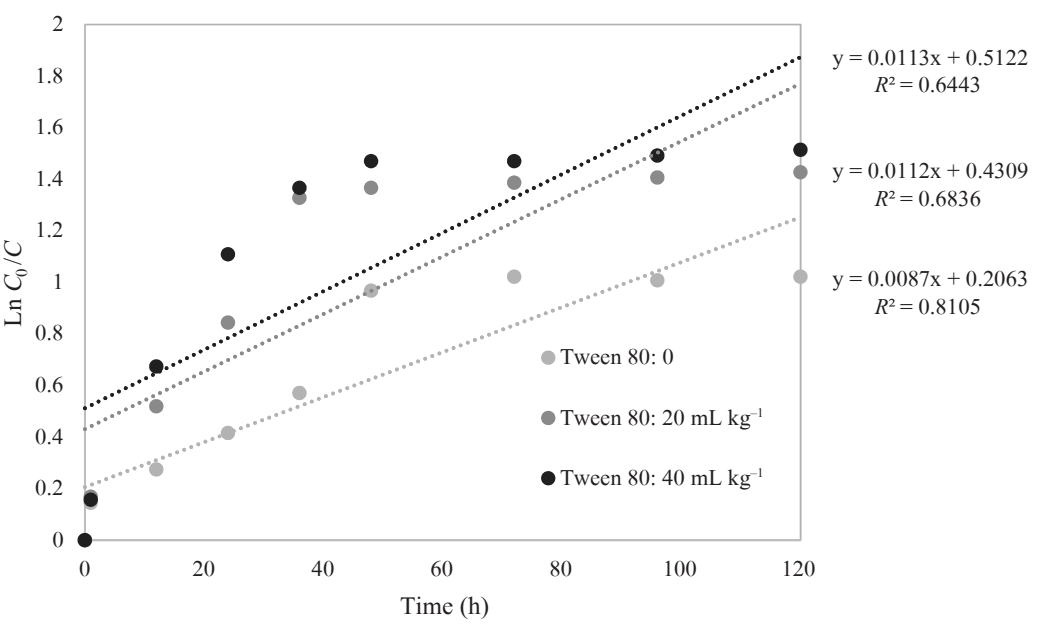

Fig. 1 - Continued 


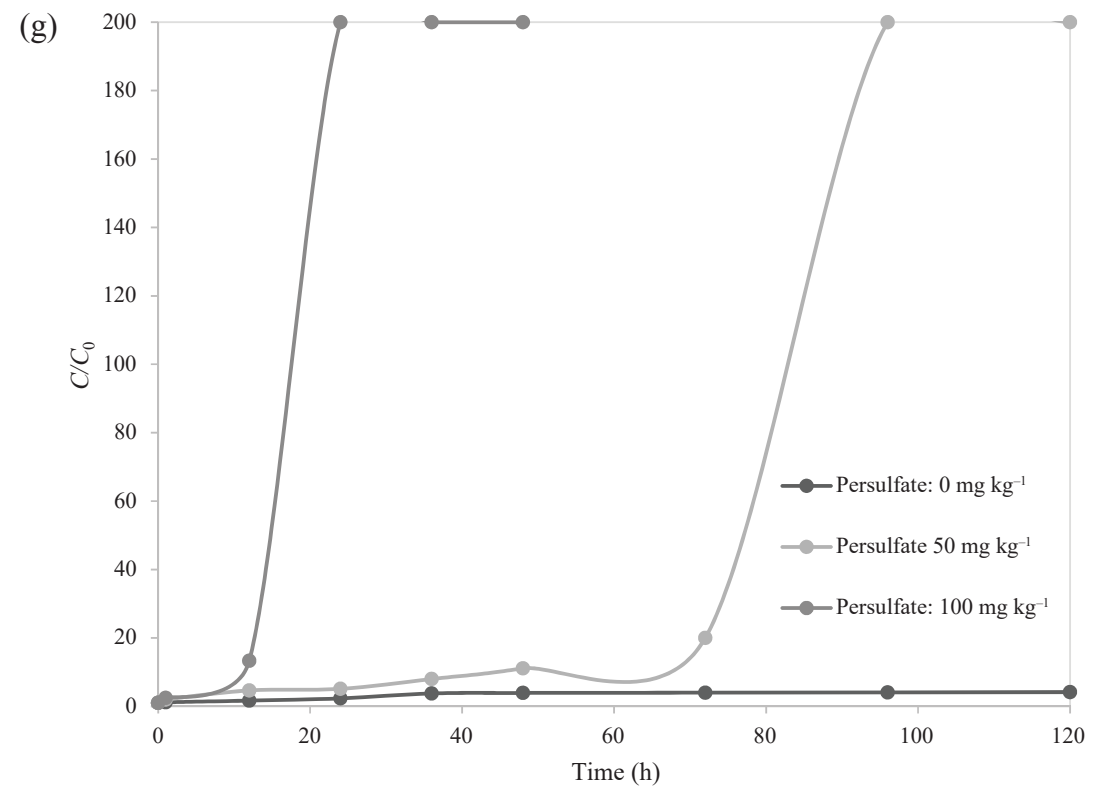

(h)

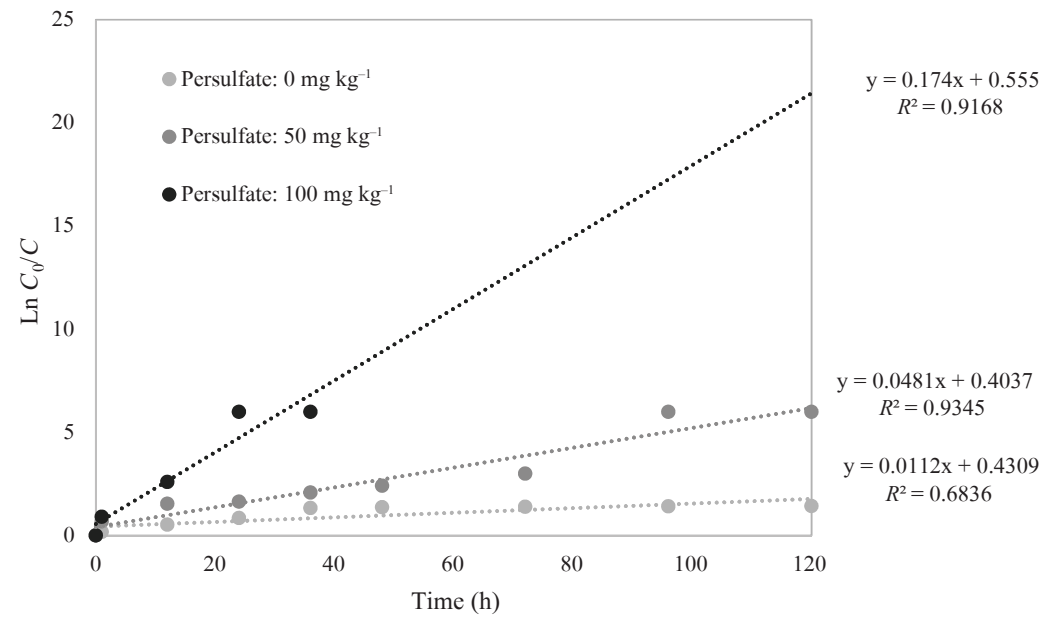

Fig. 1 - Continued.

\section{Effect of Tween 80 addition}

In the selected experimental conditions as mentioned previously, the effect of adding Tween 80 concentrations of 20 and $40 \mathrm{~mL} \mathrm{~kg}^{-1}$ in pyrene removal using EK remediation was investigated. Pyrene removal efficiency for Tween 80 concentrations of 20 and $40 \mathrm{~mL} \mathrm{~kg}^{-1}$ were 76 and $78 \%$, respectively (Fig. 1e), compared to $64 \%$ removal without surfactant addition. Surfactant used in the EK process was affected by chemical oxidation and reduction, and thus decomposed with pyrene and became harmless or low-risk material. In general, surfactant enhanced the water solubility of pyrene. Higher concentration of surfactant than the critical concentration of its micelle increases the mobility of the polycyclic aromatic hydrocarbons within the aqueous phase, and therefore increases the pyrene removal efficiency ${ }^{46}$. Results of several studies have shown that without addition of surfactant, contaminant decomposition was limited ${ }^{47}$. Adding a small amount of Tween 80 can facilitate the decomposition of endosulfan contamination by using bacteria. In effect, increasing the concentration of Tween 80 will not make a significant difference in removal efficiency ${ }^{48}$. Since an insignificant difference was observed between the removal efficiency as well as the reaction rate constant in Tween 80 concentrations of $20 \mathrm{~mL} \mathrm{~kg}^{-1}$ and $40 \mathrm{~mL} \mathrm{~kg}^{-1}$ (Fig. 1f), the value of $20 \mathrm{~mL} \mathrm{~kg}{ }^{-1}$ was selected due to less usage of chemical.

EK remediation is based on various mutual mechanisms, but the principal electron transfer reactions that occur at electrodes during the process is the electrolysis of water upon electric field application. Water decomposition (electrolysis reactions) occurs at the electrodes. The electrolysis reactions 
produce oxygen gas and hydrogen ions $\left(\mathrm{H}^{+}\right)$derived from oxidation at the anode, and produce hydrogen gas and hydroxyl $\left(\mathrm{OH}^{-}\right)$ions because of the reduction at the cathode, as illustrated in Eqs. 2 and 3:

At anode (oxidation):

$$
\begin{aligned}
& 2 \mathrm{H}_{2} \mathrm{O} \rightarrow \mathrm{O}_{2(\text { gas) }}+4 \mathrm{H}_{\text {(aq) }}^{+}+4 \mathrm{e}^{+} \\
& E^{0}=-1.229 \mathrm{~V} \text { (anode) }
\end{aligned}
$$

At cathode (reduction):

$$
\begin{aligned}
& 4 \mathrm{H}_{2} \mathrm{O}+4 \mathrm{e}^{-} \rightarrow 2 \mathrm{H}_{2 \text { (gas) }}+4 \mathrm{OH}_{\text {(aq) }}^{-} \\
& E^{0}=-0.828 \mathrm{~V} \text { (cathode) }
\end{aligned}
$$

\section{Effect of persulfate addition}

In the selected experimental conditions including voltage of $1 \mathrm{~V} \mathrm{~cm}^{-1}$, saturated moisture, Tween 80 concentration of $20 \mathrm{~mL} \mathrm{~kg}^{-1}$, pyrene concentration of $200 \mathrm{mg} \mathrm{kg}^{-1}$, reaction time of $120 \mathrm{~h}$, natural soil $\mathrm{pH}$ equal to $7 \pm 0.3$, and the effect of sodium persulfate in two concentrations of 50 and $100 \mathrm{mg} \mathrm{kg}^{-1}$ on EK remediation of pyrene was studied. Pyrene removal efficiencies for sodium persulfate concentration of $50 \mathrm{mg} \mathrm{kg}^{-1}$ and $100 \mathrm{mg} \mathrm{kg}^{-1}$ were $100 \%$ that were obtained after the reaction time of 96 and 24 h, respectively (Fig. $1 \mathrm{~g}$ and h). Firstly, persulfate moves to the soil by the electrical or electro-osmotic migration, and then it is activated by temperature and $\mathrm{pH}^{49,50}$. For activation of persulfate, it is necessary to make sure that the temperature is $45^{\circ} \mathrm{C}$. These conditions can be achieved in an electric field. As a result of high-voltage gradient, soil heats and acid is produced in the anode, which causes soil acidification and, thus, higher removal efficiency is obtained $^{51}$.

In an electric field, the incomplete solubility of salt deposits, and the mobility of sodium persulfate ions leads to the production of higher amounts of ion concentration in water. On the other hand, the amount of electrical current is reduced over time, due to the electrical migration of ions towards the electrodes. However, with addition of sodium persulfate, the electrical current significantly increased, as a result of increasing interstitial fluid concentration $^{45,52,53 .}$ Persulfates have a high potential without activation, as shown in Eq. (4):

$$
\mathrm{S}_{2} \mathrm{O}_{8}^{2-}+2 \mathrm{e}^{-} \rightarrow 2 \mathrm{SO}_{4}^{--} \quad E_{0}=2 \mathrm{~V}
$$

Persulfate provides more oxidation potential when it is activated via an activator like heat or $\mathrm{Fe}$ ions. Since the studied soil contained $\mathrm{Fe}_{2} \mathrm{O}_{3}$ iron oxides, based on XRF analysis, a possible pathway of persulfate activation is iron-based activation. The mechanism of persulfate activation through iron is as follows (Eq. (5)), which yields sulfate radicals with higher oxidation potential, in comparison to persulfate.

$$
\mathrm{S}_{2} \mathrm{O}_{8}^{2-}+2 \mathrm{Fe}^{2+} \rightarrow 2 \mathrm{SO}_{4}^{--}+2 \mathrm{Fe}^{3+} \quad E_{0}=2 \mathrm{~V}
$$

Thermal activation of persulfate in EK oxidation is also a possible mechanism, due to increasing temperature. The mechanism of persulfate oxidation via heat catalysts, which caused sulfate radicals generation to remove pyrene, can be expressed via Eqs. (6-10) as follows ${ }^{54}$ :

$$
\begin{gathered}
\mathrm{S}_{2} \mathrm{O}_{8}^{2-}+\mathrm{Heat} \rightarrow 2 \mathrm{SO}_{4}^{--} \\
\mathrm{SO}_{4}^{--}+\mathrm{H}_{2} \mathrm{O} \rightarrow \mathrm{SO}_{4}^{2-}+\mathrm{HO}^{\bullet}+\mathrm{H}^{+} \\
\mathrm{SO}_{4}^{\bullet-}+\mathrm{R} \rightarrow \mathrm{SO}_{4}^{--}-\mathrm{R} \\
\mathrm{SO}_{4}^{--}-\mathrm{R} \rightarrow \mathrm{SO}_{4}^{2-}+\mathrm{R}^{\bullet} \\
\mathrm{HO}^{\bullet}+\mathrm{R} \rightarrow \mathrm{OH}^{-}+\mathrm{R}^{\bullet}
\end{gathered}
$$

Based on Eq. 6, persulfate can be catalyzed by heat which caused production of free radicals of $\mathrm{SO}_{4}^{-55}$. The production of sulfate radicals in solution could cause the production of the hydroxyl radical $\left(\mathrm{HO}^{\circ}, E^{\circ}=+2.7 \mathrm{~V}\right)$ through radical inter-conversion reactions ${ }^{56}$. According to Eqs. 9 and 10, both $\mathrm{SO}_{4}^{-}$and $\mathrm{HO}^{\circ}$ radicals are responsible for oxidation of recalcitrant organic matter in the heat-activated persulfate oxidation process.

\section{Variations of soil pH}

The soil $\mathrm{pH}$ of the lab-scale EK setup varied as expected. The soil $\mathrm{pH}$ near the anode was 3.82 , while the $\mathrm{pH}$ near the cathode was about 10.22. The produced protons $\left(\mathrm{H}^{+}\right)$and hydroxyl $\left(\mathrm{OH}^{-}\right)$ions via electrolysis reactions (Eqs. 1 and 2) transported to the electrodes with different charges. In general, the mobility of protons is two times greater than hydroxyl ions, so the protons dominate the system and an acid front moves across the soil until it meets the hydroxyl front in a district close to cathode, where the ions may recombine to generate water. Therefore, the soil sample is separated in two different parts having various $\mathrm{pH}$ values, namely, high and low $\mathrm{pH}$ zones close to cathode and anode, respectively. The certain amounts of soil $\mathrm{pH}$ are highly dependent on the intensity of protons and hydroxyl transport, as well as soil geochemical features ${ }^{57}$.

\section{Kinetic study}

Pseudo-first-order and pseudo-second-order models were applied for kinetic studies of pyrene degradation via plotting $-\ln \left(C_{0} / C_{t}\right)$ and $1 / C_{t}$ versus time, respectively (Fig. 2a and b), in the selected experimental conditions such as $\mathrm{pH}$ value of $7 \pm 0.3$, persulfate concentration of $100 \mathrm{mg} \mathrm{kg}^{-1}$, pyrene con- 

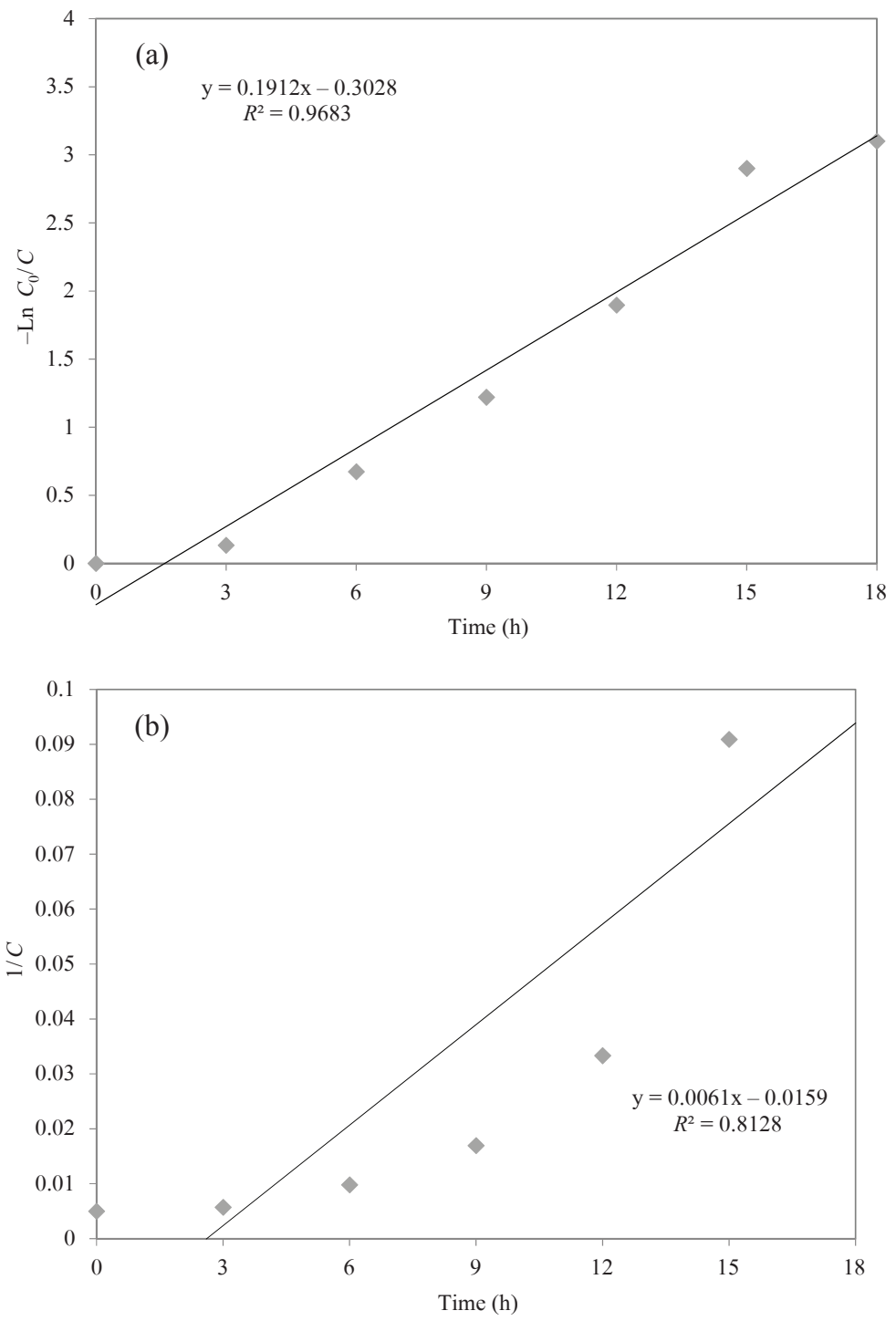

Fig. 2 - Kinetic analysis for persulfate-assisted EK of pyrene: $200 \mathrm{mg} \mathrm{kg}-1$, Tween 80: $20 \mathrm{~mL} \mathrm{kg-1}, \mathrm{pH}: 7 \pm 0.3$, reaction time: $24 \mathrm{~h}$, voltage: $1 \mathrm{~V} \mathrm{~cm}^{-1}$, moisture content: $100 \%$

centration of $200 \mathrm{mg} \mathrm{kg}^{-1}$, Tween 80 concentration of $20 \mathrm{~mL} \mathrm{~kg}$, reaction time of $24 \mathrm{~h}$, voltage of $1 \mathrm{~V} \mathrm{~cm}^{-1}$, and moisture content of $100 \%$. The equations of each kinetic model (Eq. (11), pseudo first-order and Eq. (12), pseudo second-order) are as follows ${ }^{58,59}$.

$$
\begin{gathered}
\ln C_{0} / C_{t}=k_{1} t \\
1 / C_{t}-1 / C_{0}=k_{2} t
\end{gathered}
$$

where, $C_{0}$ and $C_{t}$ are the initial and residual pyrene concentrations $\left(\mathrm{mg} \mathrm{kg}^{-1}\right)$, respectively, $t$ is the reaction time $(\mathrm{min})$, and $k_{\mathrm{n}}$ is the corresponding rate constants $(\mathrm{n}=1$ and 2$)$. The reaction kinetics of pyrene removal through the persulfate-assisted EK remediation of pyrene-contaminated soil was best fitted for pseudo first-order reaction with the regression coefficient of 0.968 and rate constant of 0.191 $\min ^{-1}$.

\section{Mineralization and intermediates of pyrene degradation}

Intermediates of persulfate-assisted EK remediation of synthetically pyrene-contaminated soil were studied in selected experimental conditions and time intervals 4 and $24 \mathrm{~h}$. A GC-MS analysis was performed exactly $4 \mathrm{~h}$ after beginning of the reaction (Fig. 3b). The main intermediate metabolites at this time were obtained as benzene $\left(\mathrm{C}_{6} \mathrm{H}_{6}\right)$, o-toluic acid $\left(\mathrm{C}_{8} \mathrm{H}_{8} \mathrm{O}_{2}\right)$, acetic acid $\left(\mathrm{C}_{2} \mathrm{H}_{4} \mathrm{O}_{2}\right)$, cyclopenta cycloheptene (azulene) $\left(\mathrm{C}_{10} \mathrm{H}_{8}\right), 1,3$-cyclopentadiene $\left(\mathrm{C}_{5} \mathrm{H}_{6}\right)$, 2-ethyl-pyridine $\left(\mathrm{C}_{7} \mathrm{H}_{9} \mathrm{~N}\right)$, naphthalene $\left(\mathrm{C}_{10} \mathrm{H}_{8}\right)$, decanoic acid $\left(\mathrm{C}_{10} \mathrm{H}_{20} \mathrm{O}_{2}\right)$, 1-chloropyrene $\left(\mathrm{C}_{16} \mathrm{H}_{9} \mathrm{Cl}\right)$ and pyrene $\left(\mathrm{C}_{16} \mathrm{H}_{10}\right)$. It is obvious that pyrene degradation had been preceded and simpler compounds and aliphatic hydrocarbons had formed. In addition, the presence of 1-chloropyrene can be attributed to the binding of $\mathrm{Cl}^{-}$produced from electrolysis reaction of saline soil and pyrene. It was found from Fig. 3c that the main final products of pyrene degradation through persulfate-assisted EK remediation were benzoic acid $\left(\mathrm{C}_{7} \mathrm{H}_{6} \mathrm{O}_{2}\right)$, dimethyl phosphinic azide $\left(\mathrm{C}_{2} \mathrm{H}_{6} \mathrm{~N}_{3} \mathrm{OP}\right)$, methoxyacetic acid $\left(\mathrm{C}_{3} \mathrm{H}_{6} \mathrm{O}_{3}\right)$, and hexadecane $\left(\mathrm{C}_{16} \mathrm{H}_{34}\right)$. Similar to the quantitative analysis, pyrene was fully removed after $24 \mathrm{~h}$ and converted to aliphatic and simpler components. Results indicated high mineralization rate, based on TPH analysis using Eq. 13:

$$
\text { Mineralization }(\%)=P_{0}-T P H / P_{0} \cdot 100
$$

where, $P_{0}$ is initial pyrene concentration and TPH represents the residual total petroleum hydrocarbons after oxidation. Based on the experimental results, TPH content of remediated soil sample was $92 \mathrm{mg} \mathrm{kg}^{-1}$, corresponding to mineralization rate of $61 \%$ in selected experimental conditions (Fig. 4).

\section{Energy consumption}

One of the most important issues in EK processes is the energy consumption, which affects the scale-up and full scale applications of this technology, since the high cost of energy is a limiting factor. Upon selecting the operating conditions in the labscale study, the energy consumption $\left(P, \mathrm{kWh} \mathrm{kg}^{-1}\right)$ was calculated using Eq. (14):

$$
P=V I t / M \cdot 1000
$$

where, $V$ is the cell voltage $\left(\mathrm{V} \mathrm{cm}^{-1}\right), I$ is the average cell current (A), $t$ is the electrolysis time (h) and $M$ is the remediated soil mass ${ }^{60-62}$. Energy consumption was calculated in the selected experimental conditions, such as initial $\mathrm{pH}$ value of $7 \pm 0.3$, voltage of $1 \mathrm{~V}$, current intensity of $0.8 \mathrm{~A}$, initial pyrene 

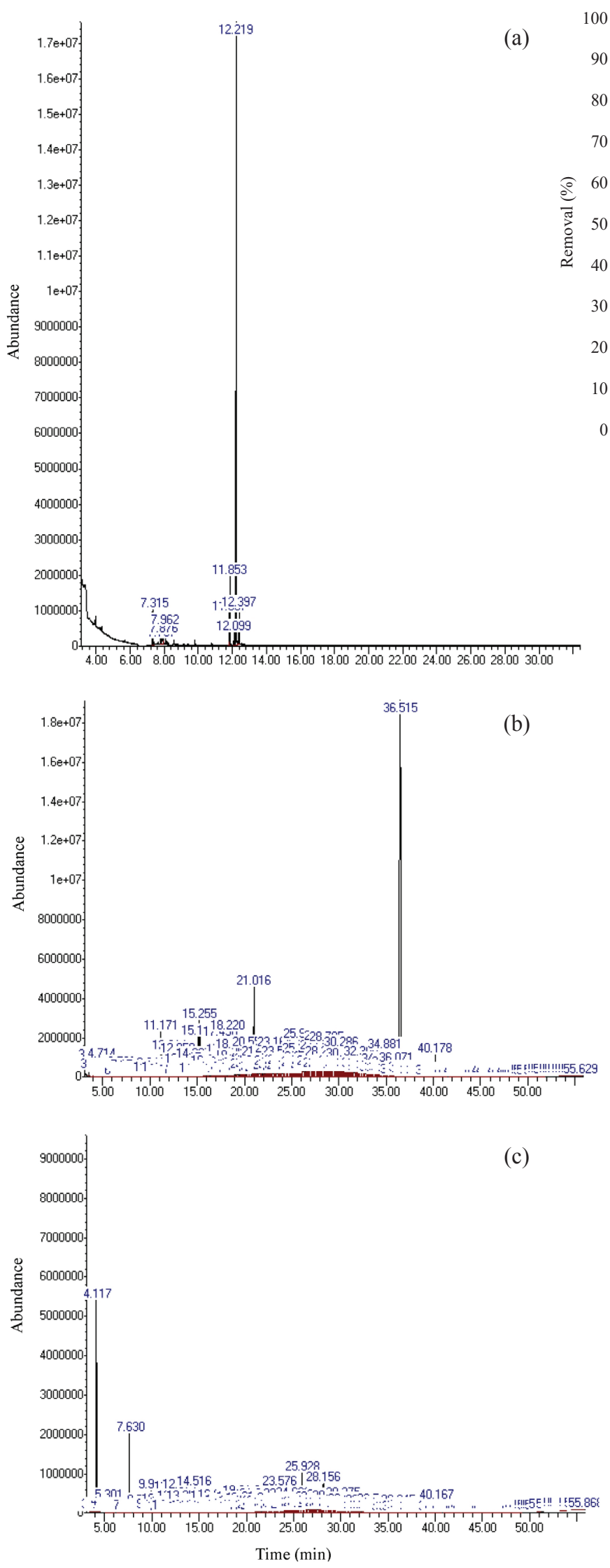

Fig. 3 - GC-MS analysis of a) unwashed soil, b) persulfate-assisted EK remediation within $4 \mathrm{~h}$, and c) persulfate-assisted EK remediation within $24 \mathrm{~h}$ under the selected conditions

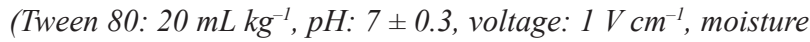
content: $100 \%$, persulfate: $100 \mathrm{mg} \mathrm{kg}^{-1}$ )

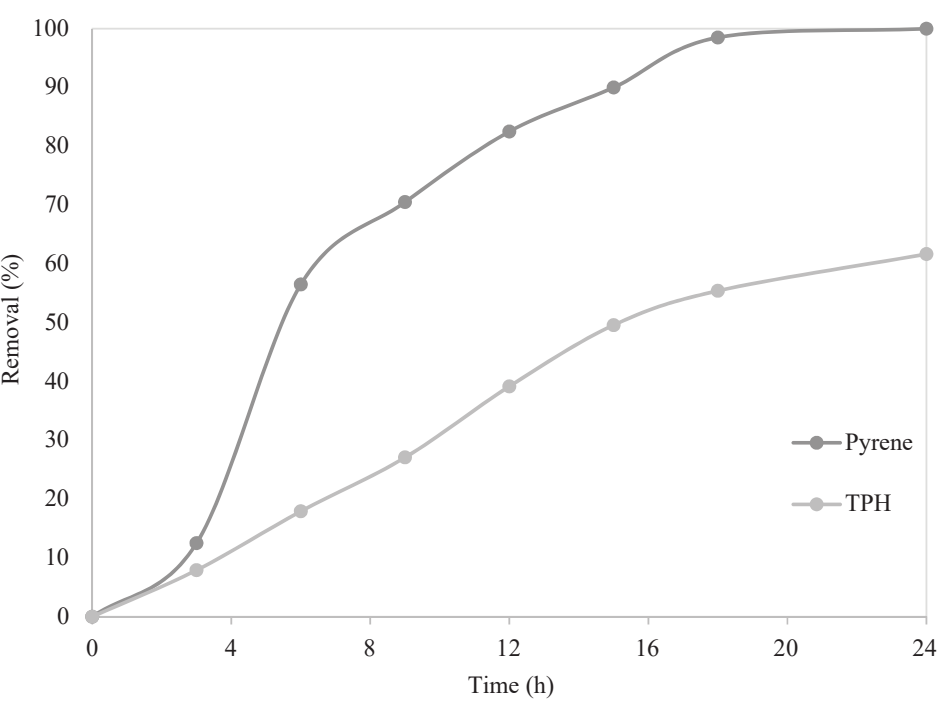

Fig. 4 - Comparison of pyrene and TPH removal using persulfate-assisted EK remediation in the same selected conditions (Tween 80: $20 \mathrm{~mL} \mathrm{~kg}^{-1}, \mathrm{pH}: 7 \pm 0.3$, voltage: $1 \mathrm{~V} \mathrm{~cm}^{-1}$, moisture content: $100 \%$, persulfate: $100 \mathrm{mg} \mathrm{kg}^{-1}$ )

concentration of $200 \mathrm{mg} \mathrm{kg}^{-1}$, persulfate concentration of $100 \mathrm{mg} \mathrm{kg}^{-1}$, Tween 80 content of $20 \mathrm{~mL} \mathrm{~kg}^{-1}$, reaction time of $24 \mathrm{~h}$, soil mass of $0.5 \mathrm{~kg}$, moisture content of $100 \%$. According to the obtained results, an energy consumption of $0.11 \mathrm{kWh} \mathrm{kg}^{-1}$ was calculated for remediation of the studied soil to obtain a complete pyrene removal. This finding is in line with literature ${ }^{63}$.

\section{Synergetic and scavenging effect}

The synergetic effect of persulfate-assisted EK system was determined at selected experimental conditions using synergy index (Eq. (15)):

$$
S I=\frac{K_{(P T E K)}}{\left(K_{P E K}\right)+\left(K_{T E K}\right)+\left(K_{E K}\right)+\left(K_{P}\right)}
$$

where, SI is the synergy index, $K$ is the pseudo-first-order kinetic constant of pyrene removal in all experimented processes (PTEK: Persulfate-assisted EK+ addition of Tween 80, EK: electrokinetic remediation, PEK: electrokinetic remediation + persulfate addition, TEK: electrokinetic remediation + addition of Tween $80, \mathrm{P}$ : oxidation through persulfate). The removal efficiency of various studied processes are presented in Fig. 5a. It is obvious that persulfate-assisted EK remediation was significantly more efficient compared to individual processes, which can be attributed to synergetic effect of all processes. This can be verified by calculation of synergy index (Fig. 5b), in which the highest value of 1.99 was obtained for persulfate-assisted EK remediation process. This significant synergy index 

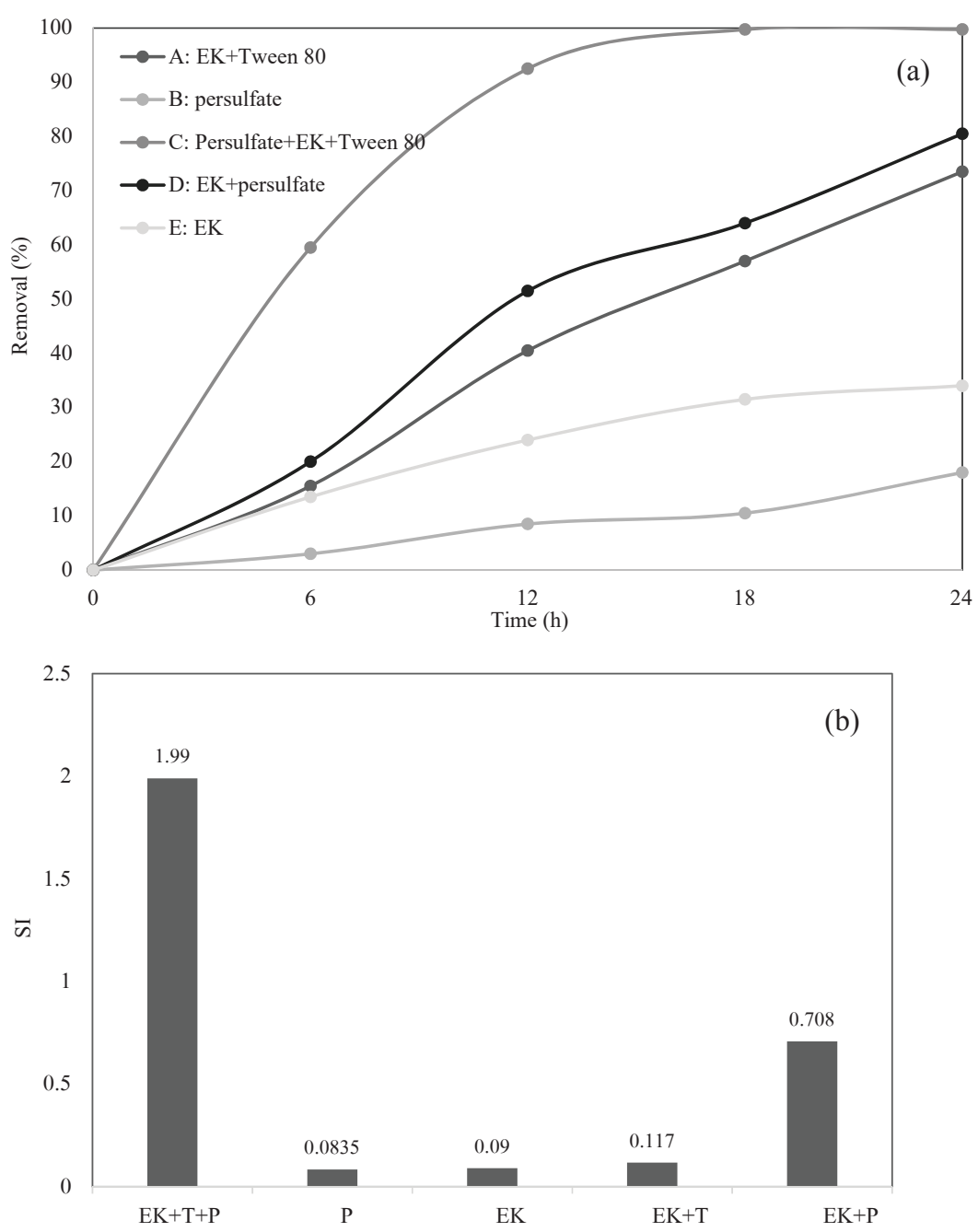

Fig. 5 - a) Pyrene removal efficiency, and b) Synergy indices in various studied processes in selected conditions (Tween 80: $20 \mathrm{~mL} \mathrm{~kg}^{-1}$, voltage: $1 \mathrm{~V} \mathrm{~cm}^{-1}$, moisture content: $100 \%$, persulfate concentration: $100 \mathrm{mg} \mathrm{kg}^{-1}$

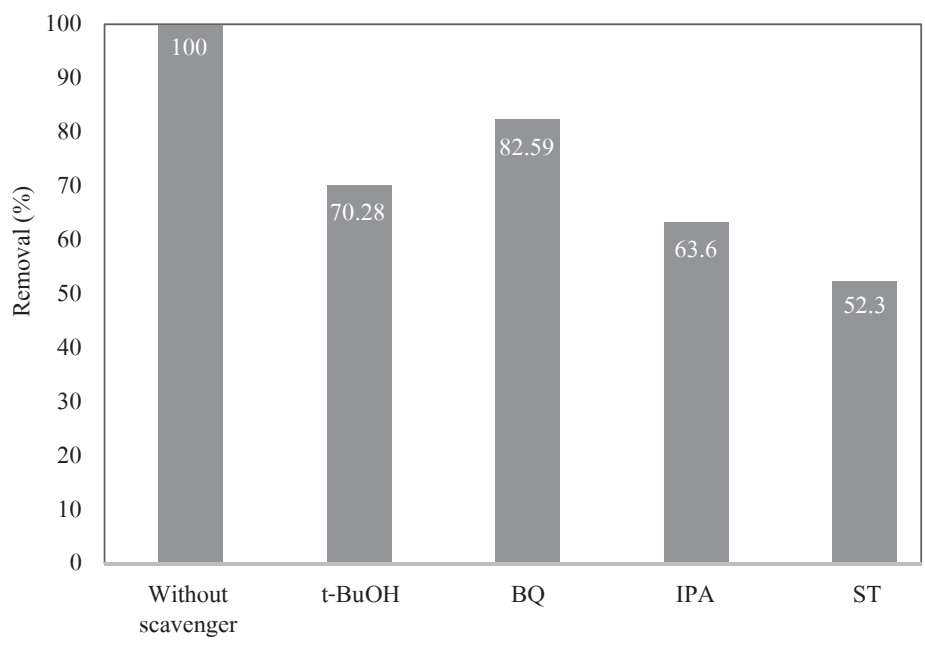

Fig. 6-Comparison of the effect of different scavengers on the performance of persulfate-assisted EK remediation of pyrene contaminated soil in selected conditions probably can be associated with the decomposition of pyrene molecules due to solubility enhancement effect of Tween 80 , oxidation influence of persulfate, as well as the oxidation function of EK reactions. These findings are in accordance with literature ${ }^{64}$.

In persulfate-assisted EK system, it is believed that the production of $\mathrm{H}_{2} \mathrm{O}_{2}$, $\mathrm{SO}_{4}{ }^{-}, \mathrm{Cl}_{2}$ and heat are responsible for pyrene destruction. Scavenging effect of non-target organics on the function of produced oxidants was investigated through addition of tert-butyl alcohol $(\mathrm{t}-\mathrm{BuOH})$, benzoquinone (BQ), sodium thiosulfate (ST) and iso-propanol (IPA) as scavenger and effective quenching agent for oxidants $\left(\mathrm{Cl}_{2}, \mathrm{H}_{2} \mathrm{O}_{2}\right)$ and $\mathrm{SO}_{4}{ }^{-}$ radicals ${ }^{65}$. It was observed that the degradation efficiency of pyrene reduced from $100 \%$ to $63.6 \%, 70.28 \%, 52.3 \%$ and $82.59 \%$, respectively, in the presence of IPA, t-BuOH, ST and BQ agents (Fig. 6). Results of scavenging experiments demonstrated that pyrene degradation was in direct relation with all the oxidation agents.

\section{EK remediation of unwashed soil}

Reliability of the persulfate-assisted EK remediation was also evaluated in the remediation of a real unwashed contaminated-soil, based on TPH analysis. In addition, the types of different hydrocarbons were also determined via GC-MS analysis. Initial TPH content of $912 \mathrm{mg} \mathrm{kg}^{-1}$ decreased to $560 \mathrm{mg} \mathrm{kg}^{-1}(38 \%$ removal) in the selected conditions like those presented in this work. The unwashed soil sample was mainly contaminated with octadecane, hexadecane, nonadecane, eicosane, heneicosane and similar compounds (Table 2). The production of various aliphatic intermediates, such as comphene, docecane, tetradecane, etc., are clear from GC-MS analysis (Fig. $7 \mathrm{a}$ and b). The high cumulative concentration of different hydrocarbons is also the main reason for lower removal efficiency of the persulfateassisted EK remediation of the unwashed soil sample. These results are in good agreement with our previous study on soil remediation with the modified Fenton oxidation ${ }^{66}$ as well as with the literature on remediation of hydrocarbon-contaminated soil 67,68 . 
Table 2-GC-MS analysis of the unwashed real hydrocarbon-contaminated soil before and after the persulfate-assisted EK (voltage: $1 \mathrm{~V} \mathrm{~cm}^{-1}$, time: $24 \mathrm{~h}, \mathrm{pH}$ : not adjusted, Tween 80: $20 \mathrm{~mL} \mathrm{~kg}^{-1}$, persulfate: $100 \mathrm{mg} \mathrm{kg} \mathrm{kg}^{-1}$ )

\begin{tabular}{|c|c|c|c|c|c|}
\hline \multicolumn{3}{|c|}{ Initial contaminant in unwashed soil } & \multicolumn{3}{|c|}{ Products of persulfate-assisted EK remediation } \\
\hline RT (min) & Substance & Chemical formula & RT (min) & Substance & Chemical formula \\
\hline 8.377 & Tricosyl trifluoroacetate & $\mathrm{C}_{25} \mathrm{H}_{47} \mathrm{~F}_{3} \mathrm{O}_{2}$ & 8.414 & Camphene & $\mathrm{C}_{10} \mathrm{H}_{16}$ \\
\hline 9.092 & Heptadecane & $\mathrm{C}_{17} \mathrm{H}_{36}$ & 15.778 & Dodecane & $\mathrm{C}_{12} \mathrm{H}_{26}$ \\
\hline 9.127 & Pentadecane & $\mathrm{C}_{15} \mathrm{H}_{32}$ & 21.174 & Tetradecane & $\mathrm{C}_{14} \mathrm{H}_{30}$ \\
\hline 9.499 & Heptadecane & $\mathrm{C}_{17} \mathrm{H}_{36}$ & 26.015 & Hexadecane & $\mathrm{C}_{16} \mathrm{H}_{34}$ \\
\hline 9.664 & Octadecane & $\mathrm{C}_{18} \mathrm{H}_{38}$ & 30.369 & Octadecane & $\mathrm{C}_{18} \mathrm{H}_{38}$ \\
\hline 9.727 & Hexadecane & $\mathrm{C}_{16} \mathrm{H}_{34}$ & 34.329 & Eicosane & $\mathrm{C}_{20} \mathrm{H}_{42}$ \\
\hline 10.048 & Nonadecane & $\mathrm{C}_{19} \mathrm{H}_{40}$ & 41.281 & Tetracosane & $\mathrm{C}_{24} \mathrm{H}_{50}$ \\
\hline 10.380 & Octatriacontyl pentafluoropropionate & $\mathrm{C}_{41} \mathrm{H}_{77} \mathrm{~F}$ & 44.359 & Heneicosane & $\mathrm{C}_{21} \mathrm{H}_{44}$ \\
\hline 11.038 & Eicosane & $\mathrm{C}_{21} \mathrm{H}_{44}$ & 47.220 & Octacosane & $\mathrm{C}_{28} \mathrm{H}_{58}$ \\
\hline 11.759 & Heneicosane & $\mathrm{C}_{21} \mathrm{H}_{44}$ & & & \\
\hline 12.354 & Docosane & $\mathrm{C}_{22} \mathrm{H}_{46}$ & & & \\
\hline 12.892 & Tricosane & $\mathrm{C}_{23} \mathrm{H}_{48}$ & & & \\
\hline 13.464 & Tetracosane & $\mathrm{C}_{24} \mathrm{H}_{50}$ & & & \\
\hline 14.540 & 1,2-Benzenedicarboxylic acid & $\mathrm{C}_{8} \mathrm{H}_{6} \mathrm{O}_{4}$ & & & \\
\hline 15.112 & Hexadecane & $\mathrm{C}_{16} \mathrm{H}_{34}$ & & & \\
\hline 15.713 & Heptacosane & $\mathrm{C}_{27} \mathrm{H}_{56}$ & & & \\
\hline 16.365 & Pentacosane & $\mathrm{C}_{25} \mathrm{H}_{52}$ & & & \\
\hline 18.556 & Propiophenone & $\mathrm{C}_{9} \mathrm{H}_{10} \mathrm{O}$ & & & \\
\hline 19.266 & Benz $[\mathrm{b}]-1,4$-oxazepine-4(5H)-thione & $\mathrm{C}_{11} \mathrm{H}_{13} \mathrm{NOS}$ & & & \\
\hline
\end{tabular}

(a)

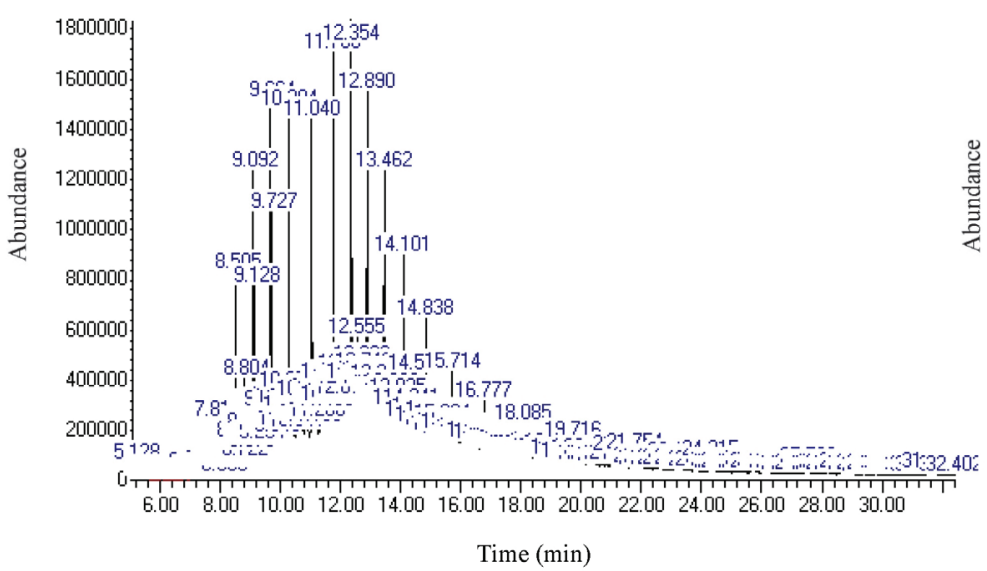

(b)

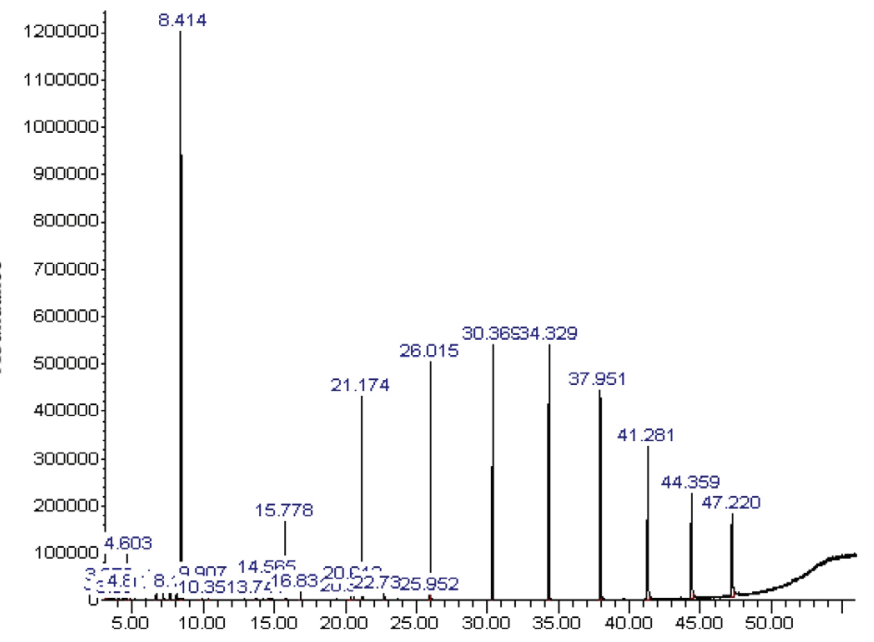

Fig. 7 - GC-MS analysis of a) unwashed hydrocarbon-contaminated soil, and b) hydrocarbon-contaminated soil after remediation with persulfate-assisted EK remediation under the selected conditions (Tween 80: $20 \mathrm{~mL} \mathrm{~kg}^{-1}$, initial pH: $7 \pm 0.3$, reaction time: 24 h, voltage: $1 \mathrm{~V} \mathrm{~cm}^{-1}$, moisture content: $100 \%$, persulfate: $100 \mathrm{mg} \mathrm{kg}^{-1}$ ) 


\section{Conclusions}

Synthetically pyrene-spiked and naturally hydrocarbon-contaminated soil samples were subjected to persulfate-assisted EK remediation in the labscale experimental setup. A total pyrene removal of $76 \%$ was obtained for initial pyrene concentration of $200 \mathrm{mg} \mathrm{kg}^{-1}$, voltage of $1 \mathrm{~V} \mathrm{~cm}^{-1}$, natural $\mathrm{pH}$, and saturated conditions in a reaction time of $120 \mathrm{~h}$. The addition of persulfate $\left(100 \mathrm{mg} \mathrm{kg}^{-1}\right)$ significantly enhanced the removal efficiency, and a complete removal was obtained in a much shorter reaction time of $24 \mathrm{~h}$. In addition, moisture was also a key factor in the enhancement of pyrene degradation, and desirable results were found to be in higher moisture contents. A removal efficiency of $29 \%$ in a low moisture content of $25 \%$ and a reaction time of $120 \mathrm{~h}$ indicated the desired ability of the studied process to be operated in soils with low moisture contents. The initial TPH concentration of $912 \mathrm{mg} \mathrm{kg}^{-1}$ decreased to $560 \mathrm{mg} \mathrm{kg}^{-1}$ in the same conditions, as determined for pyrene removal in the synthetically contaminated soil, for a naturally hydrocarbon-contaminated soil sample. Although the removal (38\%) was lower, the total mass of removed hydrocarbon was considerable. Based on the results of this research, it is obvious that persulfate-assisted EK remediation is a viable, reliable, and efficient alternative for remediation of hydrocarbon-contaminated soil in lab-scale conditions. However, further experiments are needed to optimize the operating parameters for full-scale applications.

\section{CONFLICT OF INTEREST}

The authors declare that they have no conflict of interest.

\section{ACKNOWLEDGMENTS}

This paper is issued from thesis of Nasim Mehrabi, and financial support was provided by Ahvaz Jundishapur University of Medical Sciences (Grant no: ETRC 9411).

\section{References}

1. Agrawal, N., Shahi, S. K., Degradation of polycyclic aromatic hydrocarbon (pyrene) using novel fungal strain Coriolopsis byrsina strain APC5, Int. Biodeterior. Biodegradation 122 (2017) 69. doi: https://doi.org/10.1016/j.ibiod.2017.04.024

2. Wei, J., Zhang, X., Liu, X., Liang, X., Chen, X., Influence of root components of celery on pyrene bioaccessibility, soil enzymes and microbial communities in pyrene and pyrene-diesel spiked soils, Sci. Total. Environ. 599 (2017) 50. doi: https://doi.org/10.1016/j.scitotenv.2017.04.083
3. Cristaldi, A., Oliveri Conti, G., Jho, E. H., Zuccarello, P., Grasso, A., Copat, C., Ferrante, M., Phytoremediation of contaminated soils by heavy metals and PAHs. A brief review, Environ. Tech. \& Innovation 8 (2017) 309. doi: https://doi.org/10.1016/j.eti.2017.08.002

4. Winquist, E., Björklöf, K., Schultz, E., Räsänen, M., Salonen, K., Anasonye, F., Cajthaml, T., Steffen, K. T., Jørgensen, K. S., Tuomela, M., Bioremediation of PAH-contaminated soil with fungi - From laboratory to field scale, Int. Biodeterior. Biodegrad. 86 (2013) 238. doi: https://doi.org/10.1016/j.ibiod.2013.09.012

5. Abtahi, M., Naddafi, K., Mesdaghinia, A., Yaghmaeian, K., Nabizadeh, R., Jaafarzadeh, N., Rastkari, N., Nazmara, S. Saeedi, $R$., Removal of dichloromethane from waste gas streams using a hybrid bubble column/biofilter bioreactor, J. Environ. Heal. Sci. Eng. 12 (2014) 1. doi: https://doi.org/10.1186/2052-336X-12-22

6. Deng, F., Zhang, Z., Yang, C., Guo, C., Lu, G., Dang, Z., Pyrene biodegradation with layer-by-layer assembly bio-microcapsules, Ecotoxicol. Environ. Saf. 138 (2017) 9. doi: https://doi.org/10.1016/j.ecoenv.2016.11.019

7. Saeedi, R., Khakzad, S., Koolivand, A., Dobaradaran, S., Khaloo, S. S., Jorfi, S., Abtahi, M., Transformer oils as a potential source of environmental exposure to polychlorinated biphenyls (PCBs): an assessment in three central provinces of Iran, Environ. Sci. Pollut. Res. Int. 24 (2017) 1. doi: https://doi.org/10.1007/s11356-017-9576-2.

8. Abtahi, M., Naddafi, K., Mesdaghinia, A., Yaghmaeian, K., Nabizadeh, R., Jaafarzadeh, N., Rastkari, N., Saeedi, R., Nazmara, $S$., Dichloromethane emissions from automotive manufacturing industry in Iran: Case study of the SAIPA automotive manufacturing company, Toxicol. Environ. Chem. 95 (2013) 757. doi: https://doi.org/10.1080/02772248.2013.821126

9. Jorfi, S., Rezaee, A., Mobeh-Ali, G.-A., Jaafarzadeh, N., Application of biosurfactants produced by Pseudomonas aeruginosa SP4 for bioremediation of soils contaminated by pyrene, Soil Sediment Contam. An. Int. J. 22 (2013) 890. doi: https://doi.org/10.1080/15320383.2013.770439.

10. Jorfi, S., Rezaee, A., Moheb-ali, G.-a., Jaafarzadeh, N., Pyrene removal from contaminated soils by modified Fenton oxidation using iron nano particles, J. Environ. Heal. Sci. Eng. 11 (2013) 1. doi: https://doi.org/10.1186/2052-336X-11-17.

11. Xu, J., Kong, F., Song, S., Cao, Q., Huang, T., Cui, Y., Effect of Fenton pre-oxidation on mobilization of nutrients and efficient subsequent bioremediation of crude oil-contaminated soil, Chemosphere 180 (2017) 1. doi: https://doi.org/10.1016/j.chemosphere.2017.03.087

12. Rajkumar, D., Song, B. J., Kim, J. G., Electrochemical degradation of Reactive Blue 19 in chloride medium for the treatment of textile dyeing wastewater with identification of intermediate compounds, Dye. Pigment. 72 (2007) 1. doi: https://doi.org/10.1016/j.dyepig.2005.07.015

13. Cheng, M., Zeng, G., Huang, D., Yang, C., Lai, C. Zhang, C., Liu, Y., Advantages and challenges of Tween 80 surfactant-enhanced technologies for the remediation of soils contaminated with hydrophobic organic compounds, Chem. Eng. J. 314 (2017) 98. doi: https://doi.org/10.1016/j.cej.2016.12.135

14. Cameselle, C., Pazos, M., Sanroman, M., Selection of an electrolyte to enhance the electrochemical decolourisation of indigo. Optimisation \& scale-up, Chemosphere 60 (2005) 1080. doi: https://doi.org/10.1016/j.chemosphere.2005.01.018 
15. Dai, Q., Zhou, J., Meng, X., Feng, D., Wu, C., Chen, J., Electrochemical oxidation of cinnamic acid with Mo modified $\mathrm{PbO}_{2}$ electrode: electrode characterization, kinetics and degradation pathway, Chem. Eng. J. 289 (2016) 239. doi: https://doi.org/10.1016/j.cej.2015.12.054

16. Barba, S., Villaseñor, J., Rodrigo, M. A., Cañizares, P., Effect of the polarity reversal frequency in the electrokinetic-biological remediation of oxyfluorfen polluted soil, Chemosphere 177 (2017) 120.

doi: https://doi.org/10.1016/j.chemosphere.2017.03.002.

17. Fu, R., Wen, D., Xia, X., Zhang, W., Gu, Y., Electrokinetic remediation of chromium $(\mathrm{Cr})$-contaminated soil with citric acid (CA) and polyaspartic acid (PASP) as electrolytes, Chem. Eng. J. 316 (2017) 601.

doi: https://doi.org/10.1016/j.cej.2017.01.092

18. Chowdhury, A. I., Gerhard, J. I., Reynolds, D., Sleep, B. E., $O$ 'Carroll, D. M., Electrokinetic-enhanced permanganate delivery and remediation of contaminated low permeability porous media, Water. Res. 113 (2017) 215.

doi: https://doi.org/10.1016/j.watres.2017.02.005. Epub 2017 Feb 4.

19. Souza, F., Sáez, C., Lanza, M., Cañizares, P., Rodrigo, M., Removal of chlorsulfuron and 2, 4-D from spiked soil using reversible electrokinetic adsorption barriers, Sep. Purif. Technol. 178 (2017) 147.

doi: https://doi.org/10.1016/j.seppur.2017.01.030

20. Tayybi, T., Jorfi, S., Ghaffari, S., Kujlu, R., Bioremediation of n-hexadecane contaminated soils using Pseudomonas aeruginosa bacteria isolated from coastal areas, J. Mazandaran. Univ Med. Sci. 26 (2016) 127.

21. Bezza, F. A., Chirwa, E. M. N., The role of lipopeptide biosurfactant on microbial remediation of aged polycyclic aromatic hydrocarbons (PAHs)-contaminated soil, Chem. Eng. J. 309 (2017) 563. doi: https://doi.org/10.1016/j.cej.2016.10.055.

22. Cheng, M., Zeng, G., Huang, D., Lai, C., Xu, P., Zhang, C., Liu, Y., Hydroxyl radicals based advanced oxidation processes (AOPs) for remediation of soils contaminated with organic compounds: A review, Chem. Eng. J. 284 (2016) 582. doi: https://doi.org/10.1016/j.cej.2015.09.001

23. Blyth, W., Shahsavari, E., Morrison, P. D., Ball, A. S., Biosurfactant from red ash trees enhances the bioremediation of PAH contaminated soil at a former gasworks site, J. Environ. Manage. 162 (2015) 30. doi: https://doi.org/10.1016/j.jenvman.2015.07.041

24. Chirwa, E. M. N., Mampholo, C. T., Fayemiwo, O. M., Bezza, F. A., Biosurfactant assisted recovery of the C5-C11 hydrocarbon fraction from oily sludge using biosurfactant producing consortium culture of bacteria, J. Environ. Manage. 196 (2017) 261.

doi: https://doi.org/10.1016/j.jenvman.2017.03.011

25. Fan, G., Cang, L., Fang, G., Zhou, D., Surfactant and oxidant enhanced electrokinetic remediation of a PCBs polluted soil, Sep. Purif. Technol. 123 (2014) 106. doi: https://doi.org/10.1016/j.seppur.2013.12.035

26. Fan, G., Cang, L., Gomes, H. I., Zhou, D., Electrokinetic delivery of persulfate to remediate PCBs polluted soils: Effect of different activation methods, Chemosphere $\mathbf{1 4 4}$ (2016) 138.

doi: https://doi.org/10.1016/j.chemosphere.2015.08.074. Epub 2015 Sep 5.

27. Xiong, X., Sun, B., Zhang, J., Gao, N., Shen, J., Li, J., Guan, $X$., Activating persulfate by $\mathrm{Fe}^{0}$ coupling with weak magnetic field: Performance and mechanism, Water Res. 62 (2014) 53. doi: https://doi.org/10.1016/j.watres.2014.05.042
28. Amr, S. S. A., Aziz, H. A., Adlan, M. N., Optimization of stabilized leachate treatment using ozone/persulfate in the advanced oxidation process, Waste Manag. 33 (2013) 1434 doi: https://doi.org/https://doi.org/10.1016/j.wasman.2013.01.039.

29. Qi, C., Liu, X., Lin, C., Zhang, X., Ma, J., Tan, H., Ye, W., Degradation of sulfamethoxazole by microwave-activated persulfate: Kinetics, mechanism and acute toxicity, Chem. Eng. J. 249 (2014) 6. doi: https://doi.org/https://doi.org/10.1016/j.cej.2014.03.086

30. Furman, O. S., Teel, A. L., Watts, R. J., Mechanism of base activation of persulfate, Environ. Sci Technol. 44 (2010) 6423 . doi: https://doi.org/https://doi.org/10.1021/es1013714.

31. Liang, C., Guo, Y., Mass transfer and chemical oxidation of naphthalene particles with zerovalent iron activated persulfate, Environ. Sci. Technol. 44 (2010) 8203. doi: https://doi.org/https://doi.org/10.1021/es903411a

32. Tan, C., Gao, N., Deng, Y., An, N., Deng, J., Heat-activated persulfate oxidation of diuron in water, Chem. Eng. J. 203 (2012) 294. doi:10.1016/j.cej.2012.07.005

33. Ji, Y., Shi, Y., Dong, W., Wen, X., Jiang, M., Lu, J., Thermo-activated persulfate oxidation system for tetracycline antibiotics degradation in aqueous solution, Chem. Eng. J. 298 (2016) 225. doi: https://doi.org/10.1016/j.cej.2016.04.028.

34. Weng, C. H., Tsai, K. L., Ultrasound and heat enhanced persulfate oxidation activated with $\mathrm{Fe}^{0}$ aggregate for the decolorization of CI Direct Red 23, Ultrason. Sonochem. 29 (2016) 11 doi: https://doi.org/10.1016/j.ultsonch.2015.08.012

35. Kalantary, R. R., Badkoubi, A., Mohseni-Bandpi, A., Esrafili, A., Jorfi, S., Dehghanifard, E., Baneshi, M. M., Modification of PAHs biodegradation with humic compounds, Soil Sediment Contam. An Int. J. 22 (2013) 185. doi: https://doi.org/10.1080/15320383.2013.722139

36. USEPA Method., (2008). Polycyclic Aromatic Hydrocarbons (PAHs), in: Agency, U.S.E.P. (Ed), Office of Solid Waste, Washington, DC.

37. ASTM D4972, Standard Test Method for $\mathrm{pH}$ of Soils. ASTM International, West Conshohocken, PA. (2013). doi: https://doi.org/10.1520/d4972-13, www.astm.org

38. ASTM D6913M, Standard Test Methods for Particle-Size Distribution (Gradation) of Soils Using Sieve Analysis ASTM International, West Conshohocken, PA. (2017). doi: https://doi.org/10.1520/d6913M-17, www.astm.org

39. Cameselle, $C$., Enhancement of electro-osmotic flow during the electrokinetic treatment of a contaminated soil, Electrochim. Acta. 181 (2015) 31

doi: https://doi.org/https://doi.org/10.1016/j.electacta.2015.02.191

40. Cai, Z.-P., Van Doren, J., Fang, Zh-q., Li, W.-Sh., Improvement in electrokinetic remediation of $\mathrm{Pb}$-contaminated soil near lead acid battery factory, Trans. Nonferrous Met. Soc. China. 2 (2015) 3088. doi: https://doi.org/https://doi.org/10.1016/S1003-6326(15)63937-1

41. Lu, X., Yuan, S., Electrokinetic Removal of Chlorinated Organic compounds, in: Reddy, K., Cameselle, C. (Eds.) Electrochemical Remediation Technologies for Polluted Soils, Sediments and Groundwater. E-Publishing Inc., John Wiley \& Sons, pp. 219 (2009).

doi:

https://doi.org/https://doi.org/10.1002/9780470523650.ch10 
42. Ahmed, O. A., Derriche, Z., Kameche, M., Bahmani, A., Souli, H., Dubujet, P., Fleureau, J., Electro-remediation of lead contaminated kaolinite: An electro-kinetic treatment, Chem. Eng. Process. Process Intensif. 100 (2016) 37. doi: https://doi.org/10.1016/j.cep.2015.12.002

43. Mena, E., Villaseñor, J., Rodrigo, M. A., Cañizares, P., Electrokinetic remediation of soil polluted with insoluble organics using biological permeable reactive barriers: Effect of periodic polarity reversal and voltage gradient, Chem. Eng. J. 299 (2016) 30. doi: https://doi.org/10.1016/j.cej.2016.04.049

44. $X u$, S., Guo, S., Wu, B., Li, F., Li, T., An assessment of the effectiveness and impact of electrokinetic remediation for pyrene-contaminated soil, J. Environ. Sci. 26 (2014) 2290 doi: https://doi.org/https://doi.org/10.1016/j.jes.2014.09.014

45. Ammami, M., Portet-Koltalo, F., Benamar, A., Duclairoir-Poc, C., Wang, H., LeDerf, F., Application of biosurfactants and periodic voltage gradient for enhanced electrokinetic remediation of metals and PAHs in dredged marine sediments, Chemosphere 125 (2015) 1. doi:

https://doi.org/https://doi.org/10.1016/j.chemosphere.2014.12.087

46. Gill, R. T., Harbottle, M. J., Smith, J. W. N., Thornton, S. F., Electrokinetic-enhanced bioremediation of organic contaminants: A review of processes and environmental applications, Chemosphere 107 (2014) 31. doi: https://doi.org/10.1016/j.chemosphere.2014.03.019

47. Fan, G., Cang, L., Qin, W., Zhou, C., Gomes, H. I., Zhou, $D$., Surfactants-enhanced electrokinetic transport of xanthan gum stabilized nanoPd/Fe for the remediation of PCBs contaminated soils, Sep. Purif. Technol. 114 (2013) 64. doi: https://doi.org/https://doi.org/10.1016/j.seppur.2013.04.030

48. Jayashree, R., Vasudevan, N., Effect of tween 80 added to the soil on the degradation of endosulfan by Pseudomonas aeruginosa, Int. J. Environ. Sci. Technol. 4 (2007) 203. doi: https://doi.org/https://doi.org/10.1007/BF03326275

49. Liang, C., Bruell, C. J., Marley, M. C., Sperry, K. L., Persulfate oxidation for in situ remediation of TCE. II. Activated by chelated ferrous ion, Chemosphere 55 (2004) 1225. doi:

https://doi.org/https://doi.org/10.1016/j.chemosphere.2004.01.030

50. Chen, C. F., Binh, N. T., Chen, C.-W., Dong, C.-D., Removal of polycyclic aromatic hydrocarbons from sediments using sodium persulfate activated by temperature and nanoscale zero-valent iron, J. Air Waste. Manag. Assoc. 65 (2015) 375. doi: https://doi.org/https://doi.org/10.1080/10962247.2014. 996266.

51. Villen-Guzman, M., Paz-Garcia, J. M., Rodriguez-Maroto, J. M., Garcia-Herruzo, F., Amaya-Santos, G., Gomez-Lahoz, C., Vereda-Alonso, C., Scaling-up the acid-enhanced electrokinetic remediation of a real contaminated soil, Electrochim. Acta. 181 (2015) 139.

doi:

https://doi.org/https://doi.org/10.1016/j.electacta.2015.02.067

52. Yukselen-Aksoy, Y., Reddy, K. R., Electrokinetic delivery and activation of persulfate for oxidation of PCBs in clayey soils, J. Geotech. Geoenvironmental Eng. 139 (2013) 175. doi: https://doi.org/https://doi.org/10.1061/(ASCE) GT.1943-5606.0000744.

53. Deary, M. E., Ekumankama, C. C., Cummings, S. P., Development of a novel kinetic model for the analysis of PAH biodegradation in the presence of lead and cadmium co-contaminants, J. Hazard. Mater. 307 (2016) 240. doi: https://doi.org/https://doi.org/10.1016/j.jhazmat.2015.12.015
54. Gao, Y.-Q., Gao, N.-Y., Deng, Y., Yang, Y.-Q., Ma, Y., Ultraviolet (UV) light-activated persulfate oxidation of sulfamethazine in water, Chem. Eng. J. 195 (2012) 248. doi: https://doi.org/https://doi.org/10.1016/j.cej.2012.04.084

55. Yang, S., Yang, X., Shao, X., Niu, R., Wang, L., Activated carbon catalyzed persulfate oxidation of Azo dye acid orange 7 at ambient temperature, J. Hazard. Mater. 186 (2011) 659 doi:

https://doi.org/https://doi.org/10.1016/j.jhazmat.2010.11.057

56. Shiying, Y., Ping, W., Xin, Y., Guang, W., Zhang, W., Liang, $S$., A novel advanced oxidation process to degrade organic pollutants in wastewater: Microwave-activated persulfate oxidation, J. Environ. Sci. 21 (2009) 1175. doi: https://doi.org/10.1016/S1001-0742(08)62399-2

57. Guedes, P., Mateus, E. P., Couto, N., Rodríguez, Y., Ribeiro, $A$. B., Electrokinetic remediation of six emerging organic contaminants from soil, Chemosphere 117 (2014) 124. doi: https://doi.org/10.1016/j.chemosphere.2014.06.017

58. Ahmadian, M., Yousefi, N., Van Ginkel, S. W., Zare, M. R., Rahimi, S., Fatehizadeh, A., Kinetic study of slaughterhouse wastewater treatment by electrocoagulation using $\mathrm{Fe}$ electrodes, Water Sci. Technol. 66 (2012) 754. doi: https://doi.org/10.2166/wst.2012.232

59. Huang, R., Fang, Z., Fang, X., Tsang, E. P., Ultrasonic Fenton-like catalytic degradation of bisphenol A by ferroferric oxide $\left(\mathrm{Fe}_{3} \mathrm{O}_{4}\right)$ nanoparticles prepared from steel pickling waste liquor, J. Colloid Interface Sci. 436 (2014) 258. doi: https://doi.org/10.1016/j.jcis.2014.08.035

60. Ahmadi, M., Amiri, H., Martinez, S. S., Treatment of phenol-formaldehyde resin manufacturing wastewater by the electrocoagulation process, Desalin. Water Treat. 39 (2012) 176. doi: https://doi.org/10.1080/19443994.2012.669172

61. Ahmadi, M., Ghanbari, F., Optimizing COD removal from greywater by photoelectro-persulfate process using Box-Behnken design: Assessment of effluent quality and electrical energy consumption, Environ. Sci. Pollut. Res. 23 (2016) 19350. doi: https://doi.org/10.1007/s11356-016-7139-6

62. Ahmadi, M., Ghanbari, F., Madihi-Bidgoli, S., Photoperoxi-coagulation using activated carbon fiber cathode as an efficient method for benzotriazole removal from aqueous solutions: Modeling, optimization and mechanism, J. Photochem. Photobiol. A Chem. 322 (2016) 85. doi: https://doi.org/10.1016/j.jphotochem.2016.02.025

63. Alsalka, Y., Karabet, F., Hashem, S., Evaluation of electrochemical processes for the removal of several target aromatic hydrocarbons from petroleum contaminated water, J. Environ. Monit. 13 (2011) 605-613. doi: https://doi.org/10.1039/c0em00450b

64. Chakma, S., Moholkar, V., Mechanistic analysis of sono-photolysis degradation of carmoisine, J. Ind. Eng. Chem. 33 (2016) 276. doi: https://doi.org/10.1016/j.jiec.2015.10.015

65. Jorfi, S., Kakavandi, B., Ramezani Motlagh, H., Ahmadi, M., Jaafarzadeh, N., A novel combination of oxidative degradation for benzotriazole removal using $\mathrm{TiO}_{2}$ loaded on $\mathrm{Fe}^{\mathrm{II}} \mathrm{Fe}_{2}{ }^{\mathrm{III}} \mathrm{O}_{4} @ \mathrm{C}$ as an efficient activator of peroxymonosulfate, Appl. Catal. B Environ. 219 (2017) 216. doi: https://doi.org/10.1016/j.apcatb.2017.07.035

66. Jorfi, S., Samaei, M. R., Darvishi Cheshmeh Soltani, R., Talaie Khozani, A., Ahmadi, M., Barzegar, G., Reshadatian, N., Mehrabi, N., Enhancement of the bioremediation of pyrene-contaminated soils using a hematite nanoparticle-based modified fenton oxidation in a sequenced approach, Soil Sediment Contam. An Int. J. 26 (2017) 141. doi: https://doi.org/10.1080/15320383.2017.1255875 
67. Kulik, N., Goi, A., Trapido, M., Tuhkanen, T., Degradation of polycyclic aromatic hydrocarbons by combined chemical pre-oxidation and bioremediation in creosote contaminated soil, J. Environ. Manage. 78 (2006) 382.

doi: https://doi.org/10.1016/j.jenvman.2005.05.005
68. Pan, X., Liu, J., Zhang, D., Binding of phenanthrene to extracellular polymeric substances (EPS) from aerobic activated sludge: A fluorescence study, Colloids Surfaces B Biointerfaces. 80 (2010) 103.

doi: https://doi.org/10.1016/j.colsurfb.2010.05.002 